\title{
Statins Against Drug-Induced Nephrotoxicity
}

\author{
Simin Dashti-Khavidaki ${ }^{1,2}$, Azadeh Moghaddas ${ }^{1}$, Behrooz Heydari ${ }^{1}$, Hossein Khalilii ${ }^{1}$, Mahboob Lessan-Pezeshki ${ }^{2}$ \\ ${ }^{1}$ Faculty of Pharmacy, ${ }^{2}$ Nephrology Research Center, Tehran University of Medical Sciences, Tehran, Iran.
}

Received, July 1, 2013; revised, September 27, 2013; accepted, September 29, 2013; Published September 30, 2013.

\begin{abstract}
Drug-induced nephrotoxicity (DIN) accounts for up to $60 \%$ of hospital acquired acute kidney injury with considerable morbidity and mortality. Several efforts have been made to reduce drug-induced nephrotoxicity; however, DIN remains a matter of concern. Statins with their antioxidant, anti-inflammatory and anti-apoptotic effects may have the potential to protect kidney against DIN. The present review evaluated all of the available in vitro and in vivo studies that examined the use of statins as renoprotective agents against nephrotoxic drugs. Materials for this review were obtained by searching Medline, PubMed, Scopus, Cochrane central register of controlled trials, and Cochrane database of systematic reviews. Key words used as search terms included "statin", "3-hydroxy-3-methylglutaryl-coenzyme A reductase inhibitors, "HMG-CoA reductase inhibitors", "nephroprotective", "renoprotective", "drug-induced renal diseases", "drug-induced nephrotoxicity", "drug-induced renal toxicity", "drug-induced nephropathy", "drug-induced renal side effects", and "contrastinduced nephropathy". This search was performed without time limitation. Only English language articles were included in this review. This review concluded that chronic statin user may be less prone to contrast-induced nephropathy (CIN) compared with statin non-users. Short-term high dose statin administration may also reduce the incidence of CIN in statin naïve patients. This renoprotective effect of statins against CIN is seen in low risk patients with normal kidney function or mild kidney dysfunction, but probably not in patients with moderate to severe renal dysfunction. Based on available animal data, statins may protect kidney against gentamicin-, cisplatin- and cyclosporine-induced nephrotoxicity, however, theses animal results have not yet been confirmed by human data.
\end{abstract}

This article is open to POST-PUBLICATION REVIEW. Registered readers (see "For Readers") may comment by clicking on ABSTRACT on the issue's contents page.

\section{INTRODUCTION}

Drug-induced nephrotoxicity (DIN) has been reported with a great number of drugs and contributes to approximately $20 \%$ of the hospital admissions due to acute kidney injury (AKI) and up to $60 \%$ of in-hospital AKI (1). There are several mechanisms for DIN including drug-induced oxidative stress, inflammation, increased apoptosis, and direct cytotoxicity to the tubular epithelial cells (2). 3-hydroxy-3-methylglutaryl-coenzyme A (HMG-CoA) reductase inhibitors, known as statins, are widely used in the treatment of hypercholesterolemia. Statins have pleiotropic effects including antioxidant, anti-inflammatory, antithrombotic and endothelial function improving effects irrespective of their cholesterol-lowering activity $(3,4)$. Statins show some nephroprotective effects. Some authors reported that statins decrease ischemic-reperfusion renal injury in animals due to their antioxidant and anti-inflammatory effects (5). Statins also reduce proteinuria in patients with chronic kidney disease (CKD) (6).
Some researchers proposed renoprotective effects of statins against DIN by some mechanisms including inhibition of drug accumulation in the proximal tubular cells, exerting anti-inflammatory and antithrombotic effects, up regulation of endothelial nitric oxide synthase (eNOS) and down regulation of inducible NOS (iNOS) expression (7), activation of the antioxidant defense enzymes such as heme oxygenase-1 (HO-1) (8) and thioredoxin (TRX) (9), inhibition of mitogen activated protein kinase (MAPK) and nuclear factor kappa-B (NF- $\mathrm{BB}$ ) signaling pathways (7), reducing ischemia and angiotensin II-induced AKI (10), down regulation of angiotensin receptors (11), decreased endothelin synthesis (12), and protection against complementrelated injury (13).

\footnotetext{
Corresponding Authors: Dr. H. Khalili

Khalilih@sina.tums.ac.ir or Dr. A. Moghaddas

azadeh_moghaddas@yahoo.com, Faculty of Pharmacy, Tehran University of Medical Sciences.
} 
This manuscript reviews all available articles on renoprotective properties of statins against nephrotoxic drugs.

\section{Search Method}

The present review evaluated and critiqued all of the available in vitro and in vivo studies that examined the use of statins as renoprotective agents against nephrotoxic drugs. Materials for this review were obtained by searching Medline, PubMed, Scopus, Cochrane central register of controlled trials, and Cochrane database of systematic reviews. Key words used as search terms included "statin", "3-hydroxy3-methylglutaryl-coenzyme A reductase inhibitors, "HMG-CoA reductase inhibitors", "nephroprotective", "renoprotective", "druginduced renal diseases", "drug-induced nephrotoxicity", "drug-induced renal toxicity", "drug-induced nephropathy", "drug-induced renal side effects", and "contrast-induced nephropathy". This search was performed without time limitation. Only English language articles were included in this review. In each section, studies have been reviewed chronologically.

\section{Stain and contrast -induced nephropathy}

Iodinated contrast media are widely used in diagnostic and interventional procedures with the main side effect of contrast-induced nephropathy (CIN). The incidence of CIN varies from $0.6 \%-2.3 \%$ in low risk patients to as high as $50 \%$ in high risk ones (14). CIN usually manifests as a nonoliguric and transient asymptomatic decline in renal function. After an initial vasodilatation, decrease in local vasodilating prostaglandins and nitric oxide and increase in vasoconstrictors (adenosine, angiotensin, endothelin, and vasopressin) result in vasoconstriction and blood flow shunt from medulla to the cortex. The medulla ischemia contributes to tubular injury. Direct toxic effect of contrast agents on renal tubular cells, increased reactive oxygen species (ROS) and proinflammatory cytokines, and enhanced oxygen consumption and intra-tubular pressure secondary to contrast-induced diuresis are other proposed mechanisms leading to $\operatorname{CIN}(15,16)$. Prophylactic use of antioxidant agents has been proposed as one of the modalities to decrease CIN (17).

During an animal study Al-Otaibi et al. assessed the nephroprotective effects of simvastatin against CIN. Three oral dosages of simvastatin $(15,30$, and $60 \mathrm{mg} / \mathrm{kg}$ ) were administered for four days in different groups of rats following CIN induction by single i.v administration of iohexil. Biochemical and histological results showed that simvastatin dose dependently attenuated contrast-induced rise in serum creatinine and urea concentrations, kidney structural changes and also ameliorated contrastinduced increase in oxidative stress as evaluated by renal lipid peroxidation, reduced glutathione, and myeloperoxidase (18).

Table 3 presents the metaanalysis and systematic reviews on the effect of statins on CIN incidence. There are different types of clinical studies on the effectiveness of statins against CIN. In almost all studies CIN has been defined as an increase in serum creatinine concentration of at least $0.5 \mathrm{mg} / \mathrm{dl}$ or $\geq 25 \%$ rise from patients' baseline serum creatinine values. In all studies all included patients received hydration before receiving iodinated contrast media.

For the first time in 2004 Attallah et al retrospectively assessed 1002 stable CKD patients with serum creatinine of $\geq 1.5 \mathrm{mg} / \mathrm{dl}$ who were admitted for cardiac catheterization. None of these patients received statin before admission. Upon hospitalization, 250 out of the 1002 patients were prescribed statins before catheterization while others not. All patients were followed regarding serum creatinine levels and also dialysis requirement within the first week after catheterization and also onemonth survival. The baseline serum creatinine level was similar between the two groups of patients (statin users and non-users). After catheterization, patients who received statin showed significantly lower serum creatinine concentrations (2.26 vs $3.1 \mathrm{mg} / \mathrm{dl}, \mathrm{p}=0.001)$, less CIN incidence $(17.2 \%$ vs $22.3 \%$ of patients, $\mathrm{p}=0.028$ ) and hospital stay duration (2.72 vs 3.32 days, $p=0.01)$. Dialysis requirement within first week after procedure $(2.8 \%$ vs $5.2 \%$ of patients in stainin users and non-users respectively, $\mathrm{p}=0.091$ ) and one-month survival ( 0.97 vs $0.93, p=0.105)$ were comparable between the two groups of patients (19).

Khanal et al gathered data from a prospective, audited, multicenter regional registry of patients undergoing percutaneous coronary interventions (PCI) from Michigan. Data of 28871 patients who underwent PCI and had preprocedure and peak postprocedure serum creatinine concentrations and were not receiving dialysis before PCI were used for analysis. About $38 \%$ of these patients were on statin therapy before the procedure. The mean age of patients and their preprocedure serum creatinine levels were similar between patients who were and 
were not on statin. Multivariate analysis revealed that pretreatment with statin was independently associated with lower incidence of CIN $(4.37 \%$ vs $5.93 \%, \quad \mathrm{p}<0.0001)$ and nephropathy requiring dialysis $(0.32 \%$ vs $0.49 \%, \quad \mathrm{p}=0.03)$. After adjustments for co-morbidities or using drugs that are risk or protective factors against CIN, preprocedure statin use was still associated with a significant reduction in CIN (odds ratio [OR] 0.87, $95 \%$ confidence interval $[\mathrm{CI}] 0.77-0.99, \mathrm{p}=0.03$ ) (20).

In an effort to evaluate the long-term effectiveness of statin pretreatment in reducing CIN incidence, Patti et al (2008) designed a study by enrolling 434 patients undergoing PCI and followed up prospectively for 4 years. Patients were stratified into two groups according to preprocedural statin therapy (260 patients were statin-treated and 174 statin-naive). In the statin-treated group, $59 \%$ of patients were treated by atorvastatin, $30 \%$ by simvastatin, $7 \%$ by rosuvastatin and $4 \%$ by pravastatin; mean duration of statin pretreatment was $10.6 \pm 9.1$ months. Occurrence of major adverse cardiac events (MACEs) including cardiac death, myocardial infarction, or repeat coronary revascularization and verification of continued statin therapy were the subjects for follow-up evaluation. Results showed the protective effects of pre-PCI statin therapy against CIN that consequently leads to better long-term event-free survival. The author reported that statin-treated patients had a significantly lower incidence of CIN (3\% in statintreated vs $27 \%$ in statin-naive patients, $\mathrm{p}<0.0001$; $90 \%$ risk decrease) and had better postprocedural creatinine clearance $(80 \pm 20$ vs $65 \pm 16 \mathrm{ml} / \mathrm{min}$, $\mathrm{p}<0.0001$ ). In patients who suffered CIN, postprocedural creatinine peak level was significantly lower in statin-treated versus statinnaive patients $(1.6 \pm 0.5$ vs $2.3 \pm 1.4 \mathrm{mg} / \mathrm{dl}, \mathrm{p}=0.007)$. Hospital stay was shorter in statin-treated compared with statin-naive patients $(2.2 \pm 0.5$ vs $2.4 \pm 0.6$ days, $\mathrm{p}=0.01$ ). These advantages were seen in all subgroups of patient treated by statins, except in patients with a pre-existing creatinine clearance of less than $40 \mathrm{ml} / \mathrm{min}$. Multivariate analysis showed statin pretreatment as strong predictor of decreased $\mathrm{CIN}$ risk $(\mathrm{OR}=0.10,95 \% \mathrm{CI} 0.02$ to $0.18 ; \mathrm{p}=0.001)$. CIN was a predictor of poorer outcome during follow-up. Four-year follow-ups showed significantly lower incidence of MACEs in statintreated compared with statin naïve patients $(6 \%$ vs $36 \%, \mathrm{p}<0.0001)$. Event-free survival was higher in statin-treated patients at 4 year $(94 \%$ vs $66 \%$, $\mathrm{p}<0.0001)$. The results of this study supports statins utilization as adjuvant pharmacologic therapy before PCI (21).

A Korean team (2008) conducted a prospective, randomized, placebo-controlled clinical trial (RCT), named PROMISS study, to determine the safety and efficacy of short-term administration of high dose simvastatin against CIN in 247 patients with renal insufficiency (creatinine clearance of $\leq 60 \mathrm{ml} / \mathrm{min}$ or baseline serum creatinine $\geq 1.1 \mathrm{mg} / \mathrm{dl}$ ) undergoing coronary angiography using hypoosmolar contrast agent, iohexol. One hundred and twenty-four patients received simvastatin with total dose of 160 $\mathrm{mg}$ as $40 \mathrm{mg}$ orally every 12 hours starting the evening before and ending the morning after the procedure. Others received placebo. Results did not show any difference between simvastatin and placebo groups regarding increase in serum creatinine level $(0.002 \pm 0.164$ vs $0.017 \pm 0.230$ $\mathrm{mg} / \mathrm{ml}$ respectively, $\mathrm{p}=0.559)$. The incidence of CIN did not differ between groups (simvastatin $2.5 \%$ and placebo $3.4 \%, p=1.00$ ). There were also no differences between the two groups in length of hospital stay (simvastatin 4.5 vs placebo 5.1days, $\mathrm{p}=0.390$ ) or 1 - and 6-month clinical composite outcome of death, myocardial infarction, revascularization, cerebral infarction, or dialysis $(0 \%$ in simvastatin group vs $0.8 \%$ in placebo group, $\mathrm{p}=0$ .498 for month 1 and simvastatin $2.4 \%$ vs placebo $4.1 \%, p=0.5$ for month 6 of follow-up). The authors explained their different results from previous studies by retrospective designs of those studies and resultant heterogeneous patient populations due to lack of randomization and significant differences in baseline risk factors between groups (22).

Zhao et al (2008) also assessed the effect of statins pretreatment on CIN incidence among patients with acute myocardial infarction who underwent primary angioplasty. They evaluated 279 patients, of them 56 patients were taking statins (pravastatin, simvastatin, or atorvastatin) before admission. CIN incidence was significantly lower in satin users compared with statin non-users $(7.1 \%$ vs $20.6 \% ; \mathrm{p}<0.01)(23)$.

Bouzas-Mosquera et al (2009) did not achieve Zhao results in the same patient population with larger sample size of 589 patients. In this study CIN incidence was comparable between statin users and non-users ( $15.9 \%$ vs $10.8 \%$; $\mathrm{p}=0.2)$ (24).

Another study (2009) was a comparative one on the effectiveness of two doses of simvastatin in 
preventing CIN in patients with acute coronary syndrome undergoing PCI. Two hundred and twenty-eight patients were randomly divided into simvastatin $20 \mathrm{mg}(\mathrm{n}=115)$ or simvastatin $80 \mathrm{mg}$ group $(\mathrm{n}=113)$. Patients in simvastatin $80 \mathrm{mg}$ group showed lower incidence of CIN within 48hours after contrast administration $(5.35 \%$ versus $15.7 \%)$ and also lower rise in serum creatinine, C-reactive protein (CRP), P-selectin, and intercellular adhesion molecule-1 levels (25).

Yoshida et al (2009) assessed the impact of chronic pravastatin treatment before scheduled coronary angiography or PCI on reduction of CIN incidence. They evaluated 431 patients with renal insufficiency, of them 194 patients were receiving pravastatin as chronic treatment of hypercholesterolemia. Results from logistic regression analysis revealed that pravastatin treatment independently related to the decreased risk of $\mathrm{CIN}(\mathrm{OR}=0.34, \mathrm{p}=0.011)(26)$.

Toso et al (2010) during a RCT on 304 patients with baseline estimated creatinine clearance of $<60 \mathrm{ml} / \mathrm{min}$ undergoing elective coronary angiography and/or other intervention declared an interesting data. Design of their study was very similar to PROMISS trial; however, because of older subject, lower baseline serum creatinine and cardiac ejection fraction and a higher incidence of PCI, this study population was at higher risk for CIN. Included patients divided randomly to receive atorvastatin 80 $\mathrm{mg} /$ day or matching placebo for 48 hours before and 48 hours after contrast medium administration. All patients in both groups received NAC $1200 \mathrm{mg}$ twice daily, from the day before to the day after the procedure. Results failed to show significant difference between the two groups according to mean increase in serum creatinine concentration after contrast media administration $(0.59 \pm 0.17$ in the placebo group vs $0.72 \pm 0.26 \mathrm{mg} / \mathrm{dl}$ in the atorvastatin group, $\mathrm{p}=0.31$ ). CIN occurrence did not differ between the two groups (placebo $11 \%$ and atorvastatin group $10 \%, \mathrm{p}=0.86$ ). Persistent kidney injury, defined as a 1-month increase from baseline creatinine value of at least $25 \%$, was seen in $30 \%$ and $31 \%$ of the patients in the placebo and atorvastatin group respectively $(\mathrm{P}=0.58)$. Like results obtained by PROMISS trial, this study showed that a shortterm treatment with high-dose atorvastatin before and after contrast exposure, in addition to standard intravenous hydration and oral NAC, does not decrease CIN occurrence in patients with preexisting CKD (27).
An American group (2010) declared the results of their retrospective study on 353 adult patients who underwent non-emergent PCI; of them 239 patients were on different doses of different statins therapy and 114 were not. In this study a new method of patient classification based on Mehran score, a weighted scoring system that is based on comorbidities and events during PCI, was applied to analyze the effect of statins. Despite of limitations of this study such as different kind and different doses of administered statins, obtained results were against statin use before non-emergent PCI. Data showed a non-significantly higher incidence of $\mathrm{CIN}$ in patients on statins compared with patients not used statins $(24.7 \%$ vs $14 \%)(28)$.

A Turkish team (2010) compared short-term, high-dose atorvastatin plus NAC $(80 \mathrm{mg}$ atorvastatin plus $600 \mathrm{mg}$ NAC twice daily in the first day followed by $80 \mathrm{mg}$ atorvastatin for 2 days after the procedure) or only NAC in 130 participants who undergoing coronary angiography. Patients with baseline renal dysfunction were excluded from this study. Based on their results CIN incidence was nonsignificantly lower in atorvastatin+NAC group (3.3\% vs $10 \%, p=0.135)$. Despite similar serum creatinine concentration and creatinine clearance between the two groups at the initiation of the study, serum creatinine levels were significantly lower and creatinine clearance was significantly higher in the atorvastatin+NAC group $(0.84 \pm 0.18 \quad$ vs $0.95 \pm 0.35 \mathrm{mg} / \mathrm{dl}, \quad \mathrm{p}=0.03$ and $96 \pm 22 \quad$ vs $87 \pm 23 \mathrm{ml} / \mathrm{min}, \mathrm{p}=0.037$ respectively) (29).

Acikel et al (2010) performed a RCT on 160 patients aiming to compare the effects of two different statin therapy regimens on the development of renal function deterioration following elective coronary angiography. Patients were randomized to receive either short-term atorvastatin $40 \mathrm{mg}$ /day started 3 days before coronary angiography and continued for $48 \mathrm{~h}$ after the procedure or did not receive any lipid-lowering medication as a control group. The study was also composed of additional 80 nonrandomized patients who had been receiving statins (different dose of different statins) by mean duration of $6.5 \pm 4.4$ months before contrast exposure as a chronic statin-treated group. There were no differences in renal function parameters such as serum creatinine and cystatin $\mathrm{C}$ concentrations between the short-term atorvastatin group and the chronic statin-treated group. Results was in favor of statin therapy, since post procedure serum creatinine and cystatin C levels and GFR were significantly 
better in patients using atorvastatin than those in the control group $(\mathrm{P}=0.002, \mathrm{P}=0.027$ and $\mathrm{P}=0.004$, respectively). Moreover, postprocedure serum creatinine and cystatin Clevels were significantly lower and GFR was significantly higher in chronic statin-treated patients compared with controls control subjects $(\mathrm{P}=0.006, \mathrm{P}=0.003$, and $\mathrm{P}=0.030$, respectively). By releasing these data, authors just showed that both short-term and chronic statin therapy may have a role in protecting renal function after elective coronary angiography but they addressed the main limitation of their study as nonrandomized included patients in the long-term statin-treated group (30).

ARMYDA-CIN [Atorvastatin for Reduction of Myocardial Damage during Angioplasty-ContrastInduced Nephropathy] was another trial by Patti et al (2011) to investigate the effect of short-term highdose atorvastatin load on the incidence of CIN after PCI. Statin-naive patients with acute coronary syndrome undergoing PCI $(\mathrm{n}=241)$ randomly received atorvastatin $80 \mathrm{mg} 12$ hours before intervention with another $40 \mathrm{mg}$ dose 2 hours before procedure $(\mathrm{n}=120)$ or placebo $(\mathrm{n}=121)$. There were no differences between the two groups regarding baseline serum creatinine and CRP concentrations, creatinine clearance, and history of CKD or diabetes mellitus. Thereafter all patients irrespective of their randomization were prescribed atorvastatin 40 $\mathrm{mg} /$ day for long-term. CIN incidence was lower in the atorvastatin group ( $5 \%$ vs $13.2 \%, \mathrm{p}=0.046)$. Postprocedure serum creatinine was significantly lower $(1.06 \pm 0.35$ vs $1.12 \pm 0.27, p=0.01)$ and creatinine clearance was significantly higher $(80.1 \pm$ $32.2 \mathrm{vs} 72.0 \pm 26.6 \mathrm{ml} / \mathrm{min}, \mathrm{p}=0.034)$ in atorvastatin compared with placebo group. Serum CRP peak levels $(8.4 \pm 10.5 \mathrm{vs} 13.1 \pm 20.8 \mathrm{mg} / \mathrm{l}, \mathrm{p}=0.01)$ and hospital stay $(2.9 \pm 0.9$ vs $3.2 \pm 0.8$ days, $\mathrm{p}=0.007)$ were significantly lower in atorvaststatin versus placebo group. Multivariable analysis showed that short-term pretreatment with high-dose atorvastatin was independently associated with a decreased risk of CIN (OR 0.34, 95\% CI 0.12 to $0.97, p=0.043$ ) (31).

Muñoz et al (2011) compared the effect of one of the most lipophylic statin (simvastatin) versus the most hydrophilic one (pravastatin) on CIN. They evaluated 261 patients, of them, 145 received simvastatin and 116 received pravastatin. The majority of patients underwent elective PCI. There were no differences in CIN risk factors and prophylactic strategies between the two groups.
$17.9 \%$ of patients in the simvastatin group versus $8.6 \%$ in the pravastatin group $(\mathrm{P}<0.05)$ encountered $\mathrm{CIN}$ but none of them required dialysis. Results showed that acute kidney injury (AKI) (defined as more than $0.3 \mathrm{mg} / \mathrm{dL}$ rise in serum creatinine within 48hours) occurred in $14.5 \%$ of patients in the simvastatin group compared with only $6.9 \%$ in the pravastatin group $(\mathrm{P}<0.05)$. Patients on pravastatin had a significantly lower incidence of CIN compared to patients on simvastatin and the difference between statins remained an independent predictor for the development of $\mathrm{CIN}$ in multivariate analysis (parameter estimate $0.42, \mathrm{p}=0.03$ ) (32).

$\mathrm{RCT}$ by Li et al (2012) investigated the effects of high dose atorvastatin on the incidence of CIN after emergency PCI. They randomly assigned 180 statin-naive patients with acute ST-segment elevation myocardial infarction into two groups, one group received high dose atorvastatin $(80 \mathrm{mg})$ within 12 hours of symptoms onset and before undergoing emergency PCI and the other one received placebo. Both groups continued by long-term atorvastatin (40 $\mathrm{mg}$ /day). Hence, two groups were completely similar except in getting loading dose of atorvastatin before procedure. CIN occurred lesser in atorvastatinloaded versus the control group (2.6\% vs $15.7 \%$, $\mathrm{p}=0.01$ ). Postprocedural serum creatinine concentrations were significantly lower 24 and 72 hours post procedure in the atorvastatin-loaded group $(93.4 \pm 17.1 \mathrm{vs} 112.6 \pm 23.3 \mu \mathrm{mol} / 1 \mathrm{l}$ at $48 \mathrm{~h}$ and $84.2 \pm 14.2$ vs $95.3 \pm 17.7 \mu \mathrm{mol} / 1$ at $72 \mathrm{~h}$, both $\mathrm{p}<$ 0.0001 ), however, peak serum cystatin $\mathrm{C}$ was lower in the control group $(0.51 \pm 0.14$ vs. $0.61 \pm 0.13 \mathrm{mg} / \mathrm{l}$, $\mathrm{p}<0.0001$ ). Multivariate logistic regression analysis showed that high dose atorvastatin pretreatment was independently associated with a decreased risk of CIN (OR 0.084, 95\% CI 0.015-0.462, p=0.004) (33).

Novel Approaches for Preventing or Limiting Events (NAPLES) II is a RCT on 410 patients that evaluated possible protective mechanisms of atorvastatin against $\mathrm{CIN}$ in vivo and in vitro. CKD patients enrolled to whether the atorvastatin group (80 mg within 24 hours before contrast media exposure; $n=202)$ or the control group $(n=208)$. In this study all patients pretreated by a high dose of oral NAC $1200 \mathrm{mg}$ twice daily. The primary outcome measure was the development of CIN, defined as an increase in cyctatin $\mathrm{C}$ concentration of $10 \%$ above the baseline value at 24 hours after administration of contrast agent. Twenty patients with CKD who were not scheduled for contrast 
media exposure and not enrolled in the original NAPLES II trial were assessed to address whether a single dose of atorvastatin $80 \mathrm{mg}$ may affect the serum creatinine or cystatin C levels. CIN occurred in $4.5 \%$ of patients in the atorvastatin group and $17.8 \%$ of patients in the control group $(\mathrm{p}=0.005$; $\mathrm{OR}=0.22 ; 95 \% \mathrm{CI}, 0.07-0.69)$. Based on the CIN definition in previous studies by changes in serum creatinine, there was no difference in CIN incidence between the two groups in NAPLESII trial $(3.5 \%$ in atorvastatin group vs $7.7 \%$ in the placebo group $\mathrm{p}=0.085$ ). CIN rate was lower in high dose atorvastatin- administrated group in both diabetics and nondiabetics and in patients with moderate chronic kidney disease (creatinine clearance 31-60 $\mathrm{ml} / \mathrm{min} / 1.73 \mathrm{~m}^{2}$ ) but not in patients with severe CKD (creatinine clearance less than $30 \mathrm{ml} / \mathrm{min} / 1.73 \mathrm{~m}^{2}$ ). In spite of some limitation and powerful aspects of the study, these results suggested that the beneficial effect of statin is observed only in patients at low to medium risk for CIN. In vitro results revealed that pretreatment with a high dose of atorvastatin reduced contrast-induced activation of stress kinases such as caspase-3, Jun N-terminal kinases (JNK), and p-53 and resultant apoptosis. Atorvastatin pretreatment also restored cell survival signals mediated by Akt and MAPK pathways (34).

All of the above mentioned studies on protective effect of statins against CIN have been summarized in Table 1.

Table 1. Studies on protective effects of statins against contrast-induced nephropathy (All patients in these studies received hydration before contrast media administration).

\begin{tabular}{|c|c|c|c|c|}
\hline $\begin{array}{l}\text { Type of } \\
\text { study }\end{array}$ & $\begin{array}{l}\text { Total } \\
\text { patients }\end{array}$ & Trial design & Clinical outcome & \\
\hline Retrospective & 1,002 & $\begin{array}{l}\text { Patients with stable baseline } \mathrm{SCr} \geq 1.5 \\
\mathrm{mg} / \mathrm{dl} \text {, who did not receive statin and } \\
\text { NAC underwent cardiac catheterization } \\
\text { with non-ionic contrast agent. } 250 \text { out } \\
\text { of the } 1002 \text { patients were prescribed } \\
\text { statins before catheterization while } \\
\text { others not. }\end{array}$ & $\begin{array}{l}\text { Patients who received statin showed } \\
\text { significantly lower SCr concentrations } \\
\text { and less AKI during the first week after } \\
\text { cardiac intervention. Dialysis } \\
\text { requirement within the first week after } \\
\text { procedure and one-month survival were } \\
\text { similar between the two groups. }\end{array}$ & 19 \\
\hline $\begin{array}{l}\text { Prospective, } \\
\text { observational }\end{array}$ & 29,409 & $\begin{array}{l}\text { Patients who underwent PCI and had } \\
\text { both baseline preprocedure and } \\
\text { peak postprocedure SCr levels. About } \\
38 \% \text { of these patients were on statin } \\
\text { therapy before the procedure and } 62 \% \\
\text { were not. Demographic data and } \\
\text { baseline SCr were similar between the } \\
\text { two groups. }\end{array}$ & $\begin{array}{l}\text { Pretreatment with statin was } \\
\text { independently associated with lower } \\
\text { incidence of CIN and nephropathy } \\
\text { requiring dialysis. }\end{array}$ & 20 \\
\hline $\begin{array}{l}\text { Prospective, } \\
\text { observational }\end{array}$ & 434 & $\begin{array}{l}\text { Patients who underwent PCI were } \\
\text { enrolled and followed up to } 4 \text { years. } \\
\text { Patients were stratified into two groups } \\
\text { according to preprocedural statin } \\
\text { therapy ( } 260 \text { patients statin-treated with } \\
\text { different types of statins for mean } \\
\text { duration of } 10.6 \pm 9.1 \text { months and } 174 \\
\text { statin-naive). }\end{array}$ & $\begin{array}{l}\text { Statin-treated patients had a significantly } \\
\text { lower incidence of } \mathrm{CIN} \text {, better } \\
\text { postprocedural } \mathrm{CrCl} \text {, lower } \\
\text { postprocedure peak } \mathrm{SCr} \text { level, and shorter } \\
\text { hospital stay. Benefit of statin } \\
\text { pretreatment was observed in all } \\
\text { subgroups, except in patients with a pre- } \\
\text { existing } \mathrm{CrCl}<40 \mathrm{ml} / \mathrm{min} \text {. }\end{array}$ & 21 \\
\hline $\begin{array}{l}\text { Prospective, } \\
\text { RCT }\end{array}$ & 247 & $\begin{array}{l}\text { Enrolled patients had CKD and } \\
\text { underwent coronary angiography with } \\
\text { iso-osmolar contrast agent. 124patients } \\
\text { received simvastatin ( } 160 \mathrm{mg} \text { total, } 40 \\
\text { mg orally every } 12 \text { hours starting the } \\
\text { evening before and ending the morning } \\
\text { after the procedure) or placebo (n = } \\
\text { 123). }\end{array}$ & $\begin{array}{l}\text { There was no difference between } \\
\text { simvastatin and placebo groups in mean } \\
\text { peak increase in SCr measured within } 48 \\
\text { hours after coronary angiography. } \\
\text { There were also no differences between } \\
\text { the two groups in CIN incidence, length } \\
\text { of hospital stay, or } 1-\text { and 6-month } \\
\text { clinical composite outcome of death, } \\
\text { AMI, revascularization, cerebral } \\
\text { infarction, or dialysis. }\end{array}$ & 22 \\
\hline
\end{tabular}




\begin{tabular}{|c|c|c|c|c|}
\hline Retrospective & 279 & $\begin{array}{l}\text { patients who underwent } \\
\text { primary angioplasty for their first AMI } \\
\text { were included. } 56 \text { patients were taking } \\
\text { statins (pravastatin, simvastatin, or } \\
\text { atorvastatin) before admission. }\end{array}$ & $\begin{array}{l}\text { Patients used statins before admission } \\
\text { had lower incidence of CIN. }\end{array}$ & 23 \\
\hline Retrospective & 589 & $\begin{array}{l}\text { Patients who underwent primary } \\
\text { angioplasty. }\end{array}$ & $\begin{array}{l}\text { They did not observe a protective effect } \\
\text { of statin therapy on CIN development } \\
\text { after primary angioplasty. }\end{array}$ & 24 \\
\hline $\begin{array}{l}\text { Prospective, } \\
\text { RCT }\end{array}$ & 228 & $\begin{array}{l}\text { Patients with ACS underwent PCI were } \\
\text { randomly divided into simvastatin } 20- \\
\text { mg treated group }(\mathrm{n}=115) \text { or } \\
\text { simvastatin } 80-\mathrm{mg} \text { treated group }(\mathrm{n}= \\
113) \text {. }\end{array}$ & $\begin{array}{l}\text { Patients in simvastatin } 80 \mathrm{mg} \text { group } \\
\text { showed lower incidence of CIN and also } \\
\text { lower rise in SCr, hs-CRP, P-selectin, } \\
\text { and intercellular adhesion molecule-1 } \\
\text { levels. }\end{array}$ & 25 \\
\hline $\begin{array}{l}\text { Prospective, } \\
\text { observational }\end{array}$ & 431 & $\begin{array}{l}\text { Patients with renal insufficiency, of } \\
\text { them } 194 \text { were chronic pravastatin } \\
\text { users }\end{array}$ & $\begin{array}{l}\text { Long-term pravastatin pre-treatment } \\
\text { independently related to the decreased } \\
\text { risk of CIN. }\end{array}$ & 26 \\
\hline $\begin{array}{l}\text { Prospective, } \\
\text { RCT }\end{array}$ & 304 & $\begin{array}{l}\text { Patients with baseline } \mathrm{CrCl}<60 \mathrm{ml} / \mathrm{min} \\
\text { were randomized to receive atorvastatin } \\
80 \mathrm{mg} / \text { day or placebo for } 48 \text { hours } \\
\text { before and } 48 \text { hours after contrast } \\
\text { medium administration. All patients } \\
\text { received oral NAC } \\
1,200 \mathrm{mg} 2 \text { times/day. }\end{array}$ & $\begin{array}{l}\text { Mean increase in } \mathrm{SrCr} \text { and } \mathrm{CIN} \text { incidence } \\
\text { were not significantly different between } \\
\text { atorvastatin and placebo groups. s }\end{array}$ & 27 \\
\hline Retrospective & 353 & $\begin{array}{l}239 \text { patients used statins before PCI and } \\
114 \text { were not. Patients were classified } \\
\text { based on Mehran score for risk of } \\
\text { development of CIN. }\end{array}$ & $\begin{array}{l}\text { Data showed a non-significantly higher } \\
\text { incidence of CIN in patients on statins } \\
\text { compared with patients not used statins. }\end{array}$ & 28 \\
\hline $\begin{array}{l}\text { Prospective, } \\
\text { RCT }\end{array}$ & 130 & $\begin{array}{l}\text { patients underwent coronary } \\
\text { angiography were either randomized to } \\
\text { a short-term high dose atorvastatin plus } \\
\text { NAC ( } 80 \mathrm{mg} \text { atorvastatin plus } 600 \mathrm{mg} \\
\text { NAC twice daily in the first day } \\
\text { followed with } 80 \mathrm{mg} \text { atorvastatin for } 2 \\
\text { days after the procedure) or only NAC. }\end{array}$ & $\begin{array}{l}\text { Lower incidence of } \mathrm{CIN} \text {, lower } \mathrm{SCr} \text {, and } \\
\text { higher } \mathrm{CrCl} \text { were observed in } \\
\text { atorvastatin+NAC group. }\end{array}$ & 29 \\
\hline $\begin{array}{l}\text { Prospective, } \\
\text { RCT }\end{array}$ & 160 & $\begin{array}{l}\text { patients underwent elective coronary } \\
\text { angiography were randomized equally } \\
\text { into two groups: atorvastatin } 40 \mathrm{mg} \text { /day } \\
\text { group (statin started } 3 \text { days before } \\
\text { coronary angiography) and an untreated } \\
\text { control group. An } \\
\text { additional } 80 \text { patients were included as } \\
\text { a chronic statin therapy group. }\end{array}$ & $\begin{array}{l}\text { There were no differences in } \mathrm{SCr} \text { and } \\
\text { cystatin C concentrations between the } \\
\text { short-term atorvastatin group and the } \\
\text { chronic statin-treated group. Post } \\
\text { procedure serum creatinine and cystatin } \\
\mathrm{C} \text { levels and GFR after coronary } \\
\text { angiography, were significantly better in } \\
\text { patients using atorvastatin than those in } \\
\text { the control group. Post procedure serum } \\
\text { creatinine and cystatin C levels were } \\
\text { significantly lower and GFR was } \\
\text { significantly higher in chronic statin- } \\
\text { treated patients compared with controls } \\
\text { subjects. }\end{array}$ & 30 \\
\hline RCT & 270 & $\begin{array}{l}\text { Statin-naive patients with ACS } \\
\text { undergoing PCI } \\
\text { ( } \mathrm{n}=241) \text { randomly received atorvastatin } \\
(80 \mathrm{mg} 12 \text { hours before intervention } \\
\text { with another } 40-\mathrm{mg} \text { preprocedure dose, } \\
\mathrm{n}=120) \text { or placebo }(\mathrm{n}=121) \text {. }\end{array}$ & $\begin{array}{l}\text { Postprocedure } \mathrm{SCr} \text { was significantly } \\
\text { lower, } \mathrm{CrCl} \text { was significantly higher, and } \\
\mathrm{CIN} \text { incidence was lower in atorvastatin } \\
\text { compared with placebo group. CRP peak } \\
\text { levels and hospital stay were significantly } \\
\text { lower in the atorvaststatin versus placebo } \\
\text { group. Multivariable analysis showed } \\
\text { that short-term pretreatment with high- }\end{array}$ & 31 \\
\hline
\end{tabular}




\begin{tabular}{|c|c|c|c|c|}
\hline & & & $\begin{array}{l}\text { dose atorvastatin was independently } \\
\text { associated with a decreased risk of CIN. }\end{array}$ & \\
\hline Retrospective & 261 & $\begin{array}{l}\text { The effect of one of the most lipophylic } \\
\text { statin (simvastatin) versus the most } \\
\text { hydrophilic statin (pravastatin) on CIN } \\
\text { were evaluated. They assessed } 261 \\
\text { patients, of them, } 145 \text { received } \\
\text { simvastatin and } 116 \text { received } \\
\text { pravastatin. The majority of patients } \\
\text { underwent elective PCI. }\end{array}$ & $\begin{array}{l}\text { Patients on pravastatin had a significantly } \\
\text { lower incidence of CIN and AKI } \\
\text { compared to patients on simvastatin and } \\
\text { the difference between statins remained } \\
\text { an independent predictor for the } \\
\text { development of CIN in multivariate } \\
\text { analysis. }\end{array}$ & 7 \\
\hline $\begin{array}{l}\text { Prospective, } \\
\text { RCT }\end{array}$ & 180 & $\begin{array}{l}\text { Statin-naive patients with acute ST- } \\
\text { elevated AMI randomly assigned into } \\
\text { groups which were received whether } \\
\text { high dose atorvastatin }(80 \mathrm{mg}) \text { within } \\
12 \mathrm{~h} \text { of symptom onset undergoing } \\
\text { emergency PCI or placebo followed by } \\
\text { long-term atorvastatin ( } 40 \mathrm{mg} \text { /day). }\end{array}$ & $\begin{array}{l}\text { CIN was occurred significantly lower in } \\
\text { atorvastatin loaded versus the control } \\
\text { group. Postprocedural SCr was } \\
\text { significantly lower, but serum cystatin C } \\
\text { was higher in the atorvastatin loaded } \\
\text { group. Multivariate logistic regression } \\
\text { analysis showed that high dose } \\
\text { atorvastatin pretreatment was } \\
\text { independently associated with a } \\
\text { decreased risk of CIN. }\end{array}$ & 33 \\
\hline $\begin{array}{l}\text { Prospective, } \\
\text { RCT }\end{array}$ & 410 & $\begin{array}{l}\text { This study also evaluated possible } \\
\text { mechanisms of atorvastatin against CIN } \\
\text { in vivo and in vitro. CKD patients } \\
\text { enrolled to whether the atorvastatin } \\
\text { group ( } 80 \mathrm{mg} \text { within } 24 \text { hours before } \\
\text { contrast media exposure; } \mathrm{n}=202 \text { ) or the } \\
\text { control group ( } \mathrm{n}=208) \text {. In this study all } \\
\text { patients pretreated by a high dose of } \\
\text { NAC ( } 1200 \mathrm{mg} \text { PO twice daily) and } \\
\text { sodium bicarbonate solution. }\end{array}$ & $\begin{array}{l}\text { CIN incidence was significantly lower in } \\
\text { the atorvastatin group. CIN incidence } \\
\text { was lower in high dose atorvastatin- } \\
\text { administrated group in both diabetics and } \\
\text { nondiabetics and in patients with } \\
\text { moderate but not severe CKD patients. }\end{array}$ & 34 \\
\hline \multicolumn{5}{|c|}{$\begin{array}{l}\text { ACS: acute coronary syndrome; AKI; acute kidney injury; AMI: acute myocardial infarction; CrCl:creatinine clearance; } \\
\text { CKD: chronic kidney disease; CNI: contrast-induced nephropathy; CRP: C-reactive protein; GFR: glomerular filtration } \\
\text { rate; NAC:N-acetylcysteine; PCI: percutaneous coronary intervention; RCT: randomized controlled trial; SCr: serum } \\
\text { creatinine }\end{array}$} \\
\hline
\end{tabular}

Eventually based on conflicting data, for the first time an American group published a metaanalysis to evaluate the impact of statin therapy on the incidence of CIN in patients undergoing coronary angiography until that date (2010). They reanalyzed the data from three RCTs involving 770 patients (330 in the statin group and 340 in the control group) and 7 non-randomized studies involving 31,959 patients (11,936 statin-pretreated and 20,023 statin-naive patients). All included studies in this metaanalysis have been summarized in the present article [19-24, 26-29]. This metaanalysis suggested that statin therapy might be associated with a significant reduction in the incidence of CIN in patients undergoing coronary angiography but advised caution because of the nonrandomized nature of most of the studies and the significant heterogeneity among the studies. According to the pooled estimate across the 3 prospective randomized controlled trials, statin therapy reduced the incidence of CIN compared to control by $26 \%$, where the difference between the two arms was not statistically significant (OR=0.76, 95\% CI: 0.41-1.41, $\mathrm{p}=0.39$ ). There was no significant heterogeneity in the randomized studies $\left(\mathrm{I}^{2}=0 \%, \mathrm{p}=0.48\right)$. Although the pooled analysis of the non-randomized studies (all retrospective except one which was cohort prospective) revealed a marginally significant benefit associated with statin therapy $(\mathrm{OR}=0.60$, 95\% CI:0.36-1.00, $\mathrm{p}=0.05)$ while had significant heterogeneity $\left(\mathrm{I}^{2}=88 \%, \mathrm{p}<0.00001\right)(35)$.

Thereafter Zhang et al (2011) did a metaanalysis including different types of studies such as cohort studies comparing the CIN incidence between chronic statin-users before contrast administration and a statin-naive patients $(20,21,23,26,28)$ as well as including RCTs comparing periprocedure shortterm, high-dose versus short-term, low-dose statin 
treatment or placebo $(22,25,27,29$, two non-English language RCTs). Among cohort studies included in this meta-analysis, 4 showed that chronic statin therapy before contrast administration had a protective effect against CIN. From 6 RCTs, 1194 patients were included. Under the fixed-effects model, a non-significant protective trend toward decreased CIN incidence was seen with periprocedural short-term, high-dose statin treatment (RR: $0.70 ; 95 \%$ CI: 0.48-1.02). There are some limitation in this study including combined data of cohort studies and heterogeneous RCTs and the inclusion of low-quality studies for meta-analysis (36).

Immediately after previous study, a metaanalysis on 7 RCTs (27, 29-31, two non-English articles) about periprocedural short-term atorvastatin treatment on CIN was released by a Japanese group. Results of this study were against Zhang et al's evaluation, however, just four included articles in these two meta-analysis were the same. Included articles enrolled 1251 patients undergoing percutaneous angiography or intervention. Results of pooled analysis demonstrated a statistically significant reduction in the serum creatinine changes (fixed-effects $\mathrm{MD},-0.07 \mathrm{mg} / \mathrm{dl} ; 95 \% \mathrm{CI},-0.08$ to $-0.05 \mathrm{mg} / \mathrm{dl} ; \mathrm{p}$ for effect $<0.00001 ; \mathrm{p}$ for heterogeneity $=0.12$ ), increase in the changes of creatinine clearance (random-effects MD, 6.27 $\mathrm{ml} / \mathrm{min}$; $95 \%$ CI, 1.86 to $10.68 \mathrm{ml} / \mathrm{min}$; $\mathrm{p}$ for effect $=0.005 ; \mathrm{p}$ for heterogeneity $<0.00001$ ), and reduction in the incidence of CIN (fixed-effects OR, 0.56 ; $95 \%$ CI, 0.33 to 0.95 ; $p$ for effect $=0.03$; $p$ for heterogeneity $=0.43$ ) in the atorvastatin compared with control group (37).

Zhou et al (2011) performed a metaanalysis by aiming to assess the effectiveness of short-term (2-7 days), high-dose $(80 \mathrm{mg} / \mathrm{d})$ statins in the prevention of CIN. Five RCTs $(22,25,27,29$, one non-English article that has been used in previous meta-analysis as well) with a total of 1,009 patients were included. Statins showed overall benefit in preventing CIN $(\mathrm{RR}=0.53,0.32-0.87$ with minor heterogenicity $\left.\mathrm{I}^{2}=19 \%\right)$. The subgroup analysis by stratifying the data according to patients' baseline serum creatinine, manifested that two studies done in patients with CKD Stage $\geq 3$ failed to show significant difference in CIN occurrence between the statin and matching group $(6.5 \%$ vs $7.2 \%$; $R R=0.89,0.46-1.73)$, without evidence of heterogeneity $\left(\mathrm{I}^{2}=0 \%, \mathrm{p}=0.79\right)$, while the remaining three studies conducted in patients with CKD Stage $<3$ revealed a significantly lower incidence of $\mathrm{CIN}$ in the statin groups $(3.6 \% \mathrm{vs}$ $11.9 \%)(\mathrm{RR}=0.28,0.13-0.62)$, without evidence of heterogeneity $\left(\mathrm{I}^{2}=0 \%, \mathrm{p}=0.87\right)(38)$.

Zhang et al(2011) extracted data from RCTs $(27,22,29)$ with 751 subjects. Pooled analyses with random-effect model showed that nor the CIN incidence $(\mathrm{RR}=0.76,95 \%$ CI $0.44-1.29, \mathrm{p}=0.30$, $\left.\mathrm{I}^{2}=0 \%\right)$ nor the need for renal replacement therapy $(\mathrm{RR}=0.33,95 \%$ CI $0.03-3.17, \mathrm{p}=0.34)$ were different between stain or placebo groups. This is while statin pretreatment was associated with mild reduction of serum creatinine (weighted mean difference $=-0.06 \mathrm{mg} / \mathrm{dl}, 95 \% \mathrm{CI}-0.12$ to $0.00 \mathrm{mg} / \mathrm{dl}$, $\left.\mathrm{p}=0.05, \mathrm{I}^{2}=53 \%\right)(39)$.

Another meta-analysis on 8 RCTs $(25,27$, 29,30, and three Chinese language articles two of them have been included in previous metaanalysis) among 1423 patients was performed to determine whether short-term administration of high-dose statin is superior to conventional-dose statin or placebo among patients undergoing catheterization and interventional procedures or not. Results supported that short-term high-dose statin treatment can decrease the incidence of CIN (RR: $0.51,95 \%$ CI, 0.34-0.77; $\mathrm{p}=0.001$ ) and 48 hour serum creatinine level (SMD $-0.07 \mathrm{mg} / \mathrm{dl} ; 95 \% \mathrm{CI},-0.11$ to $-0.04 \mathrm{mg} / \mathrm{dl} ; \mathrm{p}=0.00001)$. However, subgroup analysis of 2 studies could not prove reduction in CIN occurrence in patients with preexisting CKD (RR 0.90; 95\% CI, 0.49-1.65; $\mathrm{p}=0.73$ ). The authors noted that the definition of high dose statin is arbitrary, there have been no dose-finding studies with respect to statin for the prevention of CIN, and so-called high dosing is purely based on the original trial that used $80 \mathrm{mg}$ or $40 \mathrm{mg}$ dose per day (40).

Li et al (2012) by evaluating seven randomized controlled trials with a total of 1,399 patients $[22,25,27,29,30,31]$ (one of the study that have been included in this meta-analysis was not reviewed in the present article due to non-English language) assessed the effectiveness of intervention with high dose statin versus low-dose statin or placebo treatment for the prevention of CIN. The overall results base on fixed-effect model manifested that the use of short-term, high-dose statin treatment was associated with a significant reduction in CIN risk (relative risk $(\mathrm{RR})=0.51,95 \%$ CI $0.34-0.76$, $\mathrm{p}=0.001 ; \mathrm{I}^{2}=0 \%$ ). The incidence of acute renal failure requiring dialysis and decrease in the plasma CRP level was not significantly different after the use of statin $(\mathrm{RR}=0.33,95 \% \mathrm{CI} 0.05-2.10, \mathrm{p}=0.24$; $\mathrm{I}^{2}=0 \%$ and standardized mean difference (SMD) 
20.64, 95\% CI:21.57 to $0.29, \mathrm{p}=0.18, \mathrm{I}^{2}=97 \%$, respectively) (41).

Collecting above systematic reviews and metaanalysis, Kwok et al (2013) concluded that although statins show promising effect to reduce CIN incidence (RR $0.51,95 \%$ CI $0.34-0.77, \mathrm{I}^{2}=0 \%$ ), however, limitations in the studies quality and heterogeneity prevent any firm confirmation (42).

\section{Summary of contrast -induced nephropathy}

What is apparent from these meta-analyses is that making a decision and interpreting a precise conclusion is very difficult for all researchers due to different types of studies (observational studies against RCTs), different definition of dosage in the studies (such as using high dose statin for $40 \mathrm{mg}$ simvastain or atorvastatin in some studies while 80 $\mathrm{mg}$ in others), including patients with varying degree of risk factors for CIN (such as patients with varying baseline kidney function as a major risk factor for CIN), and using different types of statins (hyprophylic versus lipophylic statins) between these studies and even among patients within some particular studies. However, we can conclude that CIN may occur less frequently among chronic statin user compared with statin-naïve patients. Additionally, short-term administration of high dose hydrophilic statins may exert nephroprotective effects against CIN in satin-naïve patients.

\section{Antibiotics}

\section{Statins and aminoglycoside-induced nephrotoxicity}

Aminoglycosides are valuable gram negative coverage antibiotics because of low rates of resistance. However, nephrotoxicity is the dose limiting factor for their therapeutic use. Aminoglycoside nephrotoxicity mediated through increasing vasoconstrictors, ROS, inflammatory cytokines and apoptosis (43). Statins possess some properties that may diminish aminoglycosideinduced nephrotoxicity. These properties include anti-oxidative effects, inhibition of aminoglycoside accumulation in the proximal tubular cells, and exerting anti-inflammatory and anti-thrombotic effects. In addition up regulation of eNOS and down regulation of iNOS expressions occur by statins administration. Statins also inhibit activation of MAPK and NF- $\mathrm{BB}(44,45)$. Aminoglycoside endocytosis through multi-ligand receptor megalin is the main step in the cellular uptake of aminoglycoside and future nephrotoxicty. This process is modulated by intracellular concentration of isoprenoid pyrophosphates. Isoprenoid pyrophosphate derives from mevalonate through enzymatic activity of HMG-CoA reductase. Statins by inhibiting HMG-CoA reductase have the theoretical potential to reduce intracellular concentration of aminoglycoside. This hypothesis was approved in in vitro study of Antoine et al (45).

Ozbek et al (2009) evaluated the effect of atorvastatin against gentamicin-induced nephrotoxicity in rats. Coadministration of atorvastatin prevented gentamicin-induced increases in blood urea nitrogen (BUN) and serum creatinine levels, reduction in calculated creatinine clearance values, reduction in renal tissue glutathione (GSH) levels and elevation of kidney malondialdehyde (MDA) and NO levels. Coadministration of atorvastatin also significantly prevented gentamicininduced tubular and glomerular degeneration. The administration of atorvastatin reduced gentamicininduced over expressions of iNOS, p38-MAPK, and $\mathrm{p} 65-\mathrm{NF}-\kappa \mathrm{B}$ in rats. The authors concluded that atorvastatin can prevent gentamicin-induced renal injury via the inhibition of MAPK and NF- $\kappa B$ signaling pathways and iNOS expression (44).

During a rat study, Jabari et al evaluated the preventive effects of low, medium and high dose simvastation $(2 \mathrm{mg} / \mathrm{kg} / \mathrm{d}, 10 \mathrm{mg} / \mathrm{kg} / \mathrm{d}$, and $20 \mathrm{mg} / \mathrm{kg} / \mathrm{d}$ respectively) against nephrotoxicity of low- and high-dose gentamicin $(50 \mathrm{mg} / \mathrm{kg} / \mathrm{d}$ and $80 \mathrm{mg} / \mathrm{kg} / \mathrm{d}$ respectively). Simvastatin administration started prophylactically several days before gentamicin injection and continued all over gentamicin administration days. Increasing simvastatin dosage up to $10 \mathrm{mg} / \mathrm{kg} /$ day dose-dependently improved gentamicin-induced changes in renal histopathology and function test (46).

There is an ongoing clinical trial on the protective role of atorvastatin against amniglycoside-induced nephrotoxicty (47). The result of this human study seems to be the first results on the clinical effect of statin against aminoglycoside induced nephrotoxicity and infection outcome.

\section{Stain and vancomycin-induced nephrotoxicity \\ Vancomycin is antibiotic of choice to treat methicillin resistant $S$. aureus infections with nephrotoxicity as its major adverse effect. Prevalence of vancomycin-induced nephrotoxicity when is used as monotherapy is 5 to $10 \%$; while in high dosage or combination with other nephrotoxic}


agents, nephrotoxicity incidence increases to 14 $35 \%$ (48). Vancomycin decreases activities of antioxidant enzymes such as superoxide dismutase (SOD) and catalase (CAT) (49-50) and increases oxidative stress and free radicals $(48,50-51)$ as possible mechanisms of vancomycin-induced nephrotoxicity. Vancomycin alters the energydependent reabsorptive function of proximal tubular cells and also mitochondrial function (52).

Panonnummal et al during an animal study evaluated the renoprotective effects of atorvastatin against vancomycin-induced AKI. Atorvastation started several days before vancomycin injection and continued during vancomycin treatment and several days after that. Vancomycin decreased renal function as evidenced by increase in BUN and serum creatinine and decrease in creatinine clearance. Vancomycin also induced hypokalemia, oliguria, urinary sodium wasting, renal oxidative stress, and also some tubular and glomerular structural damages. Vancomycin-induced renal oxidative stress presented as increased renal tissue MDA, and decreased expression of antioxidant enzymes including SOD, CAT, and GHS in the kidney tissue. All vancomycin-induced renal functional, structural, and oxidative changes were mostly or completely prevented by atorvastatin administration. Authors concluded that renorpotective effect of atorvastatin against vancomycin-induced AKI is mediated through its antioxidant effect (53).

\section{Platinum derivatives cytotoxic drugs}

\section{Statin and cisplatin-induced nephrotoxicity}

Cisplatin is a cytostatic agent in the treatment of solid tumors, including cancers of the ovary, testis, bladder, head and neck, lung, cervix and endometrium. Nephrotoxicity is the major side effect with the incidence of $6-13 \%$ (1) that limits cisplatin use. Cisplatin-induced nephrotoxicity consisted of AKI, distal renal tubular acidosis, renal concentrating defect, transient proteinuria, hyperuricemia, fanconi-like syndrome, hypomagnesemia, hypocalcemia, renal salt wasting, erythropoietin deficiency, thrombotic microangiopathy, and CKD. After accumulation by renal parenchymal epithelial cells, cisplatin is metabolically converted to a more potent toxin, forms inter- and intra strand cross-links with DNA and subsequent DNA injury, mitochondrial DNA and respiration damage, activation of apoptotic pathways, and initiation of inflammatory responses
(54) and oxidative/nitrosative injury (55). It has been reported that hydroxyl radicals' generation following cisplatin administration directly or indirectly activates p38 MAPK that plays pivotal role in cisplatin-mediated kidney injury and inflammation (56). Statins have been suggested as anticancer agents based on preclinical evidence of their anti-proliferative, pro-apoptotic, anti-invasive, and radio-sensitizing properties (57). Ligands of peroxisome proliferator-activated- $\alpha$ (PPAR- $\alpha$ ) have been reported to prevent cisplatin-induced nephrotoxicity (59) and statins as ligands of PPAR$\alpha$ may possess renoprotective effect against platinum agents' nephrotoxicity. Several studies evaluated the renoprotective effects of different statins against cisplatin-induced nephrotoxicity that are reviewed here.

İşeri et al examined the protective effect of simvastatin against cisplatin-induced renal toxicity in rats. Simvastatin initiated prophylactically 5 days before a single injection of cisplatin and continued for 10 consecutive days. Cisplatin impaired kidney function as shown by increased BUN and serum creatinine concentrations and decreased creatinine clearance. This renal dysfunction was improved by simvastatin administration. Simvastatin decreased cisplatin-induced increase in myeloperoxidase (MPO) activity in the kidney but did not improve cisplatin-induced changes in renal MDA and GSH contents. Simvastatin attenuated cisplatin-induced increase in kidney tissues collagen content as indicator of fibrotic activity, and reactive oxygen metabolites. Kidney histological damages were completely reversed by simvastation. (59).

Another animal study by Fujieda et al evaluated the effect of pravastatin on cisplatin-induced nephrotoxicity. In this study low dose pravastatin was started for long time of two weeks before cisplatin-induced AKI. Cisplatin caused renal tubular damage with high renal MDA level, increased p53 up-regulated modulator of apoptosis (PUMA) expression, p53- and terminal deoxynucleotidyl transferase dUTP nick endlabeling (TUNEL)-positive cell counts, and decreased renal GSH level, GPx mRNA expression, and activity. Renal tissue sections showed cisplatininduced structural damage to the proximal tubular cells. Pretreatment with pravastatin significantly improved cisplatin-induced renal dysfunction and proteinuria and attenuated cisplatin-induced immuonohistological changes in p53- and TUNELpositive apoptotic cells in renal proximal tubular 
cells. Prophylactic administration of pravastatin also significantly prevented cisplatin-induced oxidative damage as shown by modulation in cisplatin-induced changes in renal MDA and GSH levels and kidney tissue GPx expression and activity. The authors concluded that pravastatin prevents cisplatininduced cell apoptosis through p53 signaling pathways and also via its antioxidant activity. In this study pravastatin partially, but not completely prevented cisplatin-induced nephrotoxicity. The authors hypothesized that statins induced decrease in the mTOR response may exert some renal ischemiareperfusion injury that may partly mask the nephroprotective effects of statin (60). This hypothesis was originated from Roudier's (61) and Finlay's (62) reports on statins effect on mTOR pathway. However this is an area of conflict as some authors reported that pravastatin might decrease renal reperfusion injury effect through inhibition of franesylation and prenylation of some signal transduction protein with subsequent interference with some inflammatory pathways (63).

In the third animal study by An et al the protective effects of high dose pravastatin administration shortly before cisplatin-induced acute nephrotoxicity was evaluated. Pravastatin pretreatment significantly diminished cisplatininduced increase in BUN and serum creatinine and histological damage to renal tubules. Cisplatin significantly increased renal MDA level, decreased kidney GSH level, and inhibited activities of antioxidant enzymes including CAT, SOD and GPx. All these oxidative changes significantly attenuated by pravastatin administration. Cisplatin increased kidney iNOS expression and peroxynitrite formation. These cisplatin-induced oxidative and nitrosative stimulations were partially suppressed by pravastatin. Pravastatin also reduced cisplatininduced p38 MAPK activation in the kidney tissues. The authors concluded pretreatment with pravastatin can prevent cisplatin-induced nephrotoxicity via inhibiting oxidative and nitrosative stress (64).

Khoshnoud et al assessed the impact of simvastatin on cisplatin-induced nephrotoxicity in rats using three different doses of 1,2 ,or $4 \mathrm{mg} / \mathrm{kg}$ simvastatin that were much lower than the $10 \mathrm{mg} / \mathrm{kg}$ dose that has been used in İşeri's study. In this study cisplatin-induced kidney dysfunction was not improved by simvastatin administration at any dosage (65). Inconsistent with previous studies (59, $60,64)$ in this study simvastatin in any dosage could not prevent cisplatin-induced lipid peroxidation. In this study cisplatin did not decrease renal GSH level while simvastatin at dose of $4 \mathrm{mg} / \mathrm{kg}$ significantly increased kidney tissue concentration of GSH. Renal histopathological changes were just prevented by simvastatin at dosage of $4 \mathrm{mg} / \mathrm{kg}(65)$.

We think that the failure of simvastatin to prevent cisplatin-induced nephrotoxicity in this study (65) is mainly related to the lower dose of simvastatin that have been administered in this study compared to others (59). Moreover İşeri et al in their study administered daily simvastatin injection five days before single dose injection of cisplatin and continued simvastain administration for five days after cisplatin injection as well (59) but in Khoshnoud study (65) only a single low dose of simvastatin one hour before single injection of cisplatin was used that may result in failure to see renoprotective effects of simvastatin. Additionally cisplatin dose in khoshnoud study [65] was two times the dose in İşeri et al (59) study.

It seems that protective effect of statins against platinum agents-induced nephrotoxicity is dose- and duration-dependent.

\section{Stain and carboplatin-induced nephrotoxicity}

In an in vitro and in vivo study by Cheng et al carboplatin caused AKI and increased renal ROS production, caspase-3expression and subsequent apoptotic cells. Preadministration of pravastatin significantly prevented carboplatin-induced kidney dysfunction and apoptosis and improved carboplatin-induced histomorpholoic changes and animal survival. Their in vitro survey on molecular mechanism of renoprotective effect of pravastatin against carboplatin-induced nephrotoxicity in rat NRK-52E renal tubular epithelial cells explored that pravastatin decreased ROS production, increased expression of HO-1, cyclooxygenase-2(COX-2), and 6-keto prostaglandin F1- $\alpha$ (the stable hydrolysis product of PGI2), enhanced nuclear translocation of PPAR- $\alpha$, and increased HO- 1 promoter and peroxisome proliferator response element (PPRE) activities. The authors showed interaction of PPAR$\alpha$ and PPRE on the HO-1 promoter in nuclear extracts from NRK-52E cell line following pravastatin treatment. Their in vivo experiences also showed that pravastatin induced overexpression of PPAR- $\alpha$ and HO-1 in wild-type mice. HO-1 expression was significantly diminished in PPAR- $\alpha$ knockout mice. Authors concluded that pravastatin can partially prevent carboplatin-induced nephrotoxicity and apoptosis through PPAR- $\alpha-$ 
dependent pathway. The non-complete renoprotective effect of pravastatin has been explained by its mTOR-induction activity by the authors as presented in cisplatin section as well (66).

\section{Stain and calcineurin inhibitor-induced nephrotoxicity}

Cyclosporine as the first discovered calcineurin inhibitor (CNI) initially was used in human kidney transplantation in the late 1970s. Cyclosporineinduced acute and chronic nephrotoxicity are major concerns in transplantation. Cyclosporine-induced acute nephrotoxicity includes reversible decrease in GFR with alterations in renal vascular resistance, tubular vacuolization, and thrombotic microangiopathy. Chronic Cyclosporine nephrotoxicity consisted of irreversible renal functional deterioration as a result of irreversible and progressive tubular atrophy, interstitial fibrosis, and glomerulosclerosis. Cyclosporine decreases vasodilating prostaglandins and $\mathrm{NO}$, and increases endothelin-1 (ED-1), thromboxane, angiotensin II, aldosterone, TGF- $\beta$, and ROS (67).

Li et al assessed the effect of two doses of 5 and $20 \mathrm{mg} / \mathrm{kg}$ of pravastatin on interstitial inflammation and fibrosis in a rat model of chronic cyclosporineinduced nephropathy. Chronic nephrotoxicity was induced by 4 weeks administration of cyclosporine $15 \mathrm{mg} / \mathrm{kg} /$ day. High dose, but not low dose, pravastatin normalized cyclosporine-induced changes in serum creatinine level and creatinine clearance. Pravastatin ameliorated cyclosporineinduced arteriolopathy and tubulointerstitial fibrosis. Immunohistochemistry revealed a significant increase in CRP and ED-1-positive cells, increased osteopontin mRNA expression in kidney cortex, TGF- $\beta$ mRNA over-expression and eNOS protein under-expression by cyclosporine administration. All these changes were prevented dose-dependently by pravastatin. Cyclosporine injection increased the number of renin positive glomeruli. Pravastatin coadministration did not affect intrarenal renin immunoreactivity or the number of renin-positive glomeruli (68). During another animal study, Nam et al showed that high dosage of $15 \mathrm{mg} / \mathrm{kg}$ of rosuvastatin prevented cyclosporine-induced tubular apoptosis and decreased cyclosporine-induced tubular atrophy and interstitial fibrosis. Rosuvastatin decreased intrarenal inflammation and fibrosis through decline in the expression of ED-1, TGF- $\beta$, $\alpha$-smooth muscle actin, Bax/Bcl-2 ratio, Smad 2/3, Smad 4, P-JNK (69). Based on these studies, antiinflammatory, anti-apoptotic, and anti-fibrotic effects of statins against cyclosporine nephrotoxicity seems to be dose dependent. Therefore, high dose hydrophilic statins may decrease chronic cyclosporine-induced nephrotoxicity.

All animal studies on nephroprotective effects of statins against drug-induced nephrotoxicity except of CIN have been summarized in Table 3 .

Table 3. Summerized studies on renoprotective effects of statins against drug-induced nephrotoxicity other than CIN

\begin{tabular}{|c|c|c|c|c|c|c|}
\hline Animal model & $\begin{array}{l}\text { Nephrotoxic } \\
\text { agent }\end{array}$ & & $\begin{array}{l}\text { Statin } \\
\text { administration } \\
\text { plan }\end{array}$ & Monitored indices & Results & Ref \\
\hline $\begin{array}{l}\text { Male Wistar } \\
\text { albino rats }\end{array}$ & $\begin{array}{l}\text { Gentamicin } \\
100 \mathrm{mg} / \mathrm{kg} / \mathrm{d} \\
\text { for } 10 \text { days }\end{array}$ & i.p. & $\begin{array}{l}\text { Atorvastatin } \\
\text { suspension via } \\
\mathrm{NG} \text { tube } \\
10 \mathrm{mg} / \mathrm{kg} / \mathrm{d} \text { for } 10 \\
\text { days }\end{array}$ & $\begin{array}{l}\mathrm{BUN}, \mathrm{SCr}, \mathrm{CrCl} \text {; renal } \\
\text { tissue } \mathrm{MDA}, \mathrm{NO} \text {, and } \\
\text { GSH; } \\
\text { Renal histopathological } \\
\text { examination }\end{array}$ & $\begin{array}{l}\text { Atorvastatin prevented gentamicin- } \\
\text { induced rises in BUN and } \mathrm{SCr} \text { and } \\
\text { decrease in } \mathrm{CrCl} \text {. Atorvastatin also } \\
\text { prevented gentamicin-induced } \\
\text { elevation in renal tissue MDA and NO } \\
\text { and decrease in kidney GSH, and } \\
\text { decreased gentamicin induced tubular } \\
\text { and glomerular histologic damage }\end{array}$ & 44 \\
\hline $\begin{array}{l}\text { Sprague- } \\
\text { Dawley rats }\end{array}$ & $\begin{array}{l}\text { Gentamicin } \\
50 \mathrm{mg} / \mathrm{kg} / \mathrm{d} \\
80 \mathrm{mg} / \mathrm{kg} / \mathrm{d} \\
\text { injection } \\
\text { 8days }\end{array}$ & or & $\begin{array}{l}\text { Simvastatin 2, } \\
10,0 \mathrm{r} 20 \mathrm{mg} / \mathrm{kg} / \mathrm{d} \\
\text { for } 12 \text { days via } \\
\text { gavage, started } \\
\text { 4days before } \\
\text { gentamicin }\end{array}$ & $\begin{array}{l}\mathrm{SCr}, \mathrm{CrCl}, \quad \text { kidney } \\
\text { histology }\end{array}$ & 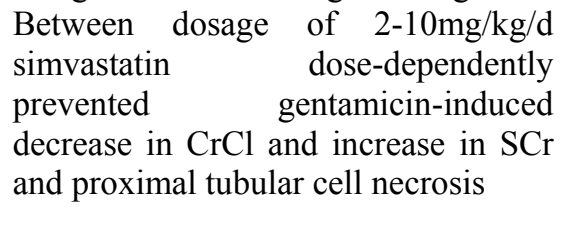 & 46 \\
\hline $\begin{array}{l}\text { Proximal } \\
\text { tubule cell } \\
\text { lines }\end{array}$ & $\begin{array}{l}\text { Gentamicin } \\
0.25 \mathrm{mg} / \mathrm{ml}\end{array}$ & & $\begin{array}{l}\text { Coadministration } \\
\text { of simvastatin } \\
10 \mu \mathrm{M} \quad \text { or } \\
\text { rosuvastatin } 30\end{array}$ & $\begin{array}{l}\text { Intracellular gentamicin } \\
\text { concentration; GTP- } \\
\text { binding protein } \\
\text { prenylation }\end{array}$ & $\begin{array}{l}\text { All three statins reduced Intracellular } \\
\text { gentamicin concentration and GTP- } \\
\text { binding protein prenylation }\end{array}$ & 45 \\
\hline
\end{tabular}




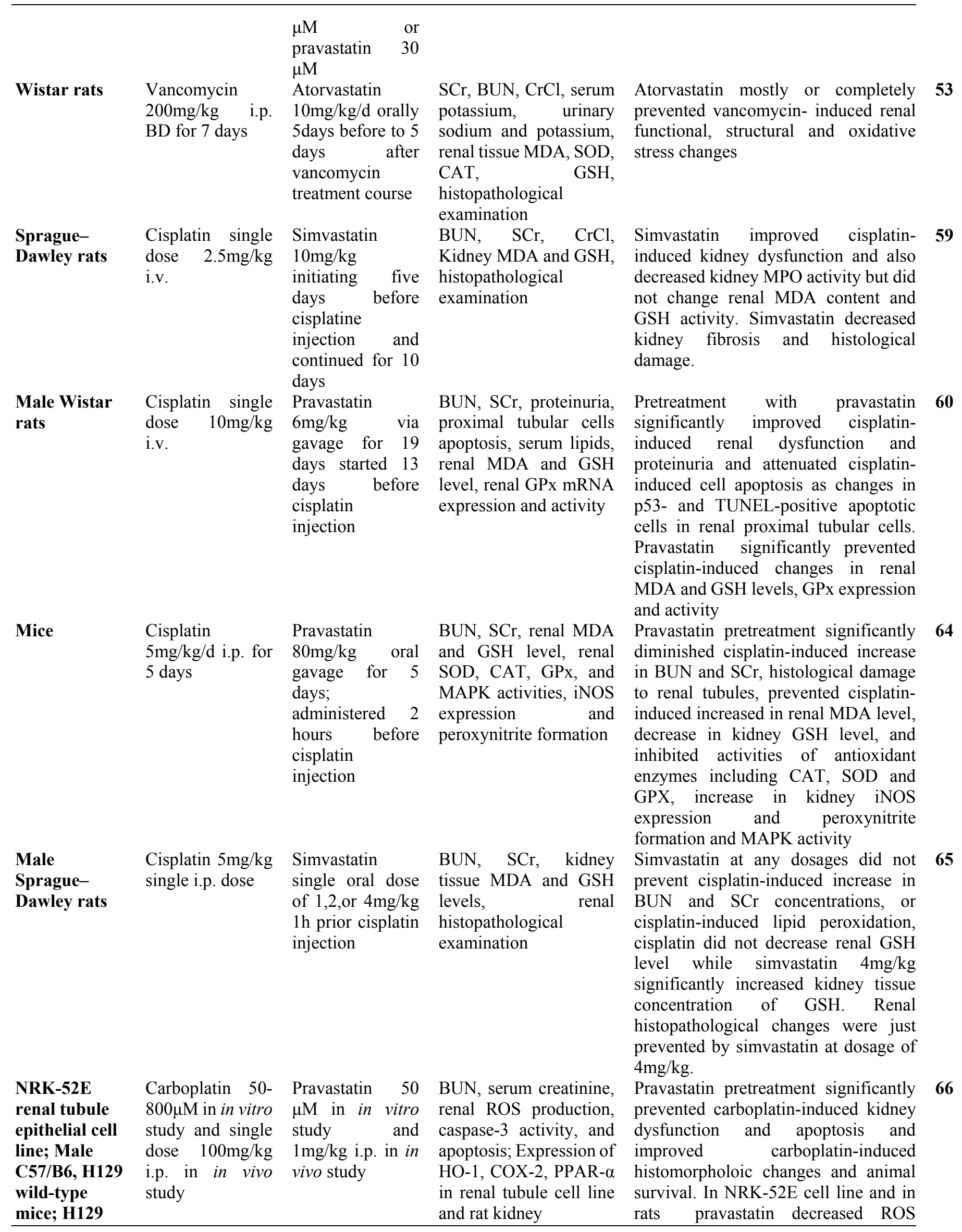


PPARo-

knockout

mice

Male

Sprague-

Dawley rats
Cyclosporine Pravastatin

$15 \mathrm{mg} / \mathrm{kg}$ s.c. for $20 \mathrm{mg} / \mathrm{kg}$ po 4 weeks
5, $\mathrm{SCr}$, osteopontine, TGF and eNO mRNA expression; histopathological examination production and increased expression of HO-1, COX-2, PPAR- $\alpha$.

$\mathrm{CrCl}$; High dose pravastatin normalized cyclosporine-induced changes in $\mathrm{SCr}$ and $\mathrm{CrCl}$. Pravastatin dosedependently ameliorated cyclosporineinduced arteriolopathy and tubulointerstitial fibrosis, increase in CRP and ED-1-positive cells, increased renal osteopontin mRNA and TGF- $\beta$ mRNA over-expression and eNOS protein under-expression, but did not change intrarenal renin immunoreactivity or the number of renin-positive glomeruli

$\mathrm{SCr}, \mathrm{CrCl}$; expression of Rosuvastatin decreased cyclosporineED-1, TGF- $\beta, \quad \alpha-$ smooth muscle actin, $\mathrm{Bax} / \mathrm{Bcl}$ ratio, $\mathrm{Smad} 2 / 3$, Smad 4, P-JNK; histopathological examination induced renal dysfunction, tubular apoptosis, tubular atrophy, and interstitial fibrosis through decline in expression of ED-1, TGF- $\beta, \alpha$-smooth muscle actin, Bax/Bcl ratio, $\operatorname{Smad} 2 / 3$, Smad 4, P-JNK
Li et al

(68)
Male
Sprague-
Cyclosporine
Rosuvastatin
Dawley rats

BUN: blood urea nitrogen; CAT: catalase; COX-2: cyclooxygenase-2; CrCl: creatinine clearance; CIN; contrast-induced nephropathy; CRP: C-reactive protein; ED-1: endothelin-1; eNOS: endothelial nitric oxide synthase; GPx: glutathione peroxidase; GSH: reduced glutathione; HO-1: heme oxygenase-1; iNOS:inducible nitric oxide synthase; i.p.: intraperitoneal; i.v: intravenous; K: potassium; MAPK: mitogen activated protein kinase; MDA: malondialdehyde; MPO: myeloperoxidase; $\mathrm{Na}$ : sodium; NG: nasogastric; NO: nitric oxide; PPAR- $\alpha$ : peroxisome proliferator-activated- $\alpha$; ROS: reactive oxygen species; s.c.: subcutaneous; SCr: serum creatinine; SOD: superoxide dismutase; TGF- $\beta$ : tansformin growth factor- $\beta$; TUNEL: terminal deoxynucleotidyl transferase dUTP nick end-labeling;

\section{Conclusion and Expert opinion}

Drug-induced nephrotoxicity accounts for about $60 \%$ of hospital-acquired AKI with high mortality and morbidity (1). Several drugs with antioxidant, anti-inflammatory, and anti-apoptotic effects have been evaluated to prevent drug-induced nephrotoxicity (70-73). Statins that widely used in the treatment of hypercholesterolemia have pleiotropic effects including antioxidant, antiinflammatory, antithrombotic and endothelial function improving actions (3-4). Statins show some nephroprotective effects against ischemiareperfusion renal injury in animals (5) and also reduce proteinuria in various types of CKD patients (6).

Some studies have evaluated protective effects of statins against drug-induced nephrotoxicity. Studies on drugs other than contrast agents have only be done in animals. Only studies on contrast-induced nephropathy have been performed in clinical settings with conflicting results. These contradictory results are due to different studies' designs (retrospective, prospective observational, or randomized controlled trials), and different types, doses or duration of statin administration. Approximate similarities between these different studies are similar definition for CIN and hydration of all patients before contrast media administration. Almost all retrospective and prospective observational studies showed lower incidence of CIN in chronic statin users compared with those not on statin $(19-21,23,26,32)$. Some discrepancy between few other retrospective studies $(24,28)$ may be due to including patients with different types of risk factors for CIN occurrence. It seems that statin therapy is more protective against CIN in patients with normal renal function or mild kidney dysfunction but not in patients with moderate to severe CKD. Among available randomized clinical trials it appears that high-dose statin therapy is more efficacious than low-dose statin in reducing CIN incidence. Different types of statins may show different efficacy as seen more protection against CIN by more hydrophilic statin, pravastatin, compared with more lipophilic one, simvastatin (22, $25,27,29-31,33-34)$. We have to consider that publication bias may result in more accessible to studies that support nephroprotective effect of statins against CIN. Due to widespread use of statins in 
patients suffering coronary artery diseases, randomized, placebo-controlled trials to assess the impact of statins in CIN prevention during cardiovascular procedures are difficult to perform. However based on our comprehensive review, it seems that chronic statin users may suffer fewer incidences of CIN or peak serum creatinine concentrations following coronary angiography compared with satin naïve patients. Among short term statin recipients, patients who were administered high-dose of more hydrophilic statins such as pravastatin and atorvastatin showed more promising impacts against CIN. Statins may protect kidney against CIN only in patients with mild, but not moderate to severe renal dysfunction.

Regarding antibiotics, all three available animal studies (22-26) on statin renoprotective effects against gentamicin-induced nephrotoxicity showed promising results. Antioxidant action of statins may play role in its nephroprotective effect. The results of ongoing clinical trial (47) will clarify the real clinical effect of statin against gentamicin-induced nephrotoxicity. Considering the results generated from statins effects against other nephrotoxic agents such as contrast media and also animal studies on aminoglycoside-induced nephrotoxicity, we have to consider that using different doses (low versus high doses) of different types (hydrophilic versus lipophylic) of statins may show different impacts against aminoglycoside or vancomycin-induced nephrotocicity. Additionally in animal studies statins were administered prophylactically several days before antibiotic administration. Predicting the time to need aminoglycoside or vancomycin administration in clinical settings is hard and statins would be of clinical importance if they could show the nephroprotective effects against aminoglycoside/vancomycin nephrotoxicity upon concurrent not prophylactic administration.

Based on available animal studies statins showed protective effects against nephrotoxicity of platinum agents probably through their anti-oxidative effects (59-60, 64, 66). It seems that protective effect of statins against platinum agents-induced nephrotoxicity is dose- and duration dependent. Using higher dose of statins several days before and throughout platinum agents' injection period exerts more nephroprotective effects.

Since statins have been widely used in cancer patients and have also shown anti-cancer effect in some studies $(57,74-76)$, there is no fear regarding reducing cytotoxic effects of cisplatin by statin co- administration. It seems to be the time to design a clinical trial on nephroprotective effect of statins against valuable cytotoxic agent cisplatin to possibly overcome its main clinical use limitation of nephrotoxicity.

Based on the available animal studies, high dosage of hydrophilic statins may attenuate cyclosporine-induced chronic nephrotoxicity. As obvious, hyperlipidemia is a prevalent co-morbidity in patients who undergo solid organ transplantation mainly heart and kidney transplantation. Hyperlipidemia is also a common side effect of immunosuppressive drugs including calcineurin inhibitors and steroids. Statins have been introduced as treatment of choice in these patients (77-78). Additionally, it has been shown that statins improve graft survival in heart transplant recipients (79-80). Therefore, statin administration in kidney or heart transplant recipients under cyclosporine therapy would be of several advantages. More hydrophilic statins have less pharmacokinetic interactions with cyclosporine and resultant side effects such as rhabdomyolysis. Among these hydrophilic statins we have to consider the important side effects of rosuvastatin-induced proteinuria and acute kidney injury (81). It is proposed to evaluate the protective effect of statins against cyclosporine-induced nephrotoxicity at-least through retrospective and prospective observational studies on patients of big transplant centers who are receiving statins for other clinical indications. These preliminary findings may be a basis for decision on performing controlled clinical trials.

\section{Proposed Research}

Most retrospective studies and controlled clinical trials have shown protective effect of statins against contrast-induced nephropathy in low risk patients. Based on their data, assessment of protective effect of statins against CIN in high-risk patients is proposed in larger clinical trials using high dose of more hydrophilic statins such as pravastatin and atorvastatin.

Due to dose-dependent effect of statins against nephrotoxicity of contrast media, aminoglycosides, platinum agents and cyclosporine, we propose dose finding studies for clear definition of high dose statins against nephrotoxicity of these drugs.

Regarding different impacts of hydrophilic and lipophylic statins against drug-induced nephrotoxicity, we recommend animal and clinical 
studies to better differentiate between nephroprotective effects of different types of statins.

We recommend designing animal studies using concurrent, not prophylactic administration of statin with aminoglycoside/vancomycin to clarify nephroprotective effects of statins in real clinical settings.

Considering animal findings and pleiotropic effects of statins, designing clinical trials on protective effect of statins against cisplatin- and cyclosporine-induced nephrotoxicity are recommended.

Conflict of interest: None of the authors declare conflict on interest with the contents of this article.

\section{REFERENCES}

1. Nolin TD, Himmelfarb J. Drug-induced kidney disease, in Dipiro JT(eds), Pharmacotherapy, a pathophysiologic approach. 8th ed: Mc Graw Hill companies Inc,New York, 2011.

2. Yao X, Panichpisal K, Kurtzman N, Nugent K. Cisplatin nephrotoxicity: A review. Am J Med Sci, 2007; 334(2):115-124

3. Schachter M. Chemical, pharmacokinetic and pharmacodynamic properties of statins: an update. Fundam Clin Pharmacol, 2005; 19(1): 117-125

4. Epstein M, Campese VM. Pleiotropic effects of 3hydroxy-3-methylglutaryl coenzyme A reductase inhibitors on renal function. Am J Kidney Dis, 2005; 45(1): 2-14

5. Sharyo S, Yokota-Ikeda N, Mori M, Kumagai K, Uchida K, Ito K, Burne-Taney MJ, Rabb H, Ikeda M. Pravastatin improves renal ischemia-reperfusion injury by inhibiting the mevalonate pathway. Kidney Int, 2008; 74(5):577-584

6. Nakamura T, Sato E, Fujiwara N, Kawagoe Y, Takeuchi M, Maeda S, Yamagishi S. Atorvastatin reduces proteinuria in non-diabetic chronic kidney disease patients partly via lowering serum levels of advanced glycation end products (AGEs). Oxid Med Cell Longev, 2010; 3(5):304-307

7. Ozbek E, Cekmen M, Ilbey YO, Simsek A, Polat EC, Somay A. Atorvastatin prevents gentamicin-induced renal damage in rats through the inhibition of $\mathrm{p} 38$ MAPK and NF-кB pathway. Ren Fail, 2009; 31(5):382-392

8. Chen HH, Chen TW, Lin H. Pravastatin attenuates carboplatin-induced nephrotoxicity in rodents via peroxisome proliferator-activated receptor $\alpha$ regulated heme-oxygenase-1. Mol Pharmacol, 2010; 78(1):36-45

9. Haendeler J, Hoffmann J, Zeither AM, Dimmeler S. Antioxidant effects of statins via S-nitrosylation and activation of thioredoxin in endothelial cells: A novel vasculoprotective function of statin. Circulation, 2004; 110(7):856-861

10. Park JK, Müller DN, Mervaala EM, Dechend R, Fiebeler A, Schmidt F, Bieringer M, Schäfer O, Lindschau C, Schneider W, Ganten D, Luft FC, Haller H, Cerivastatin prevents angiotensin IIinduced renal injury independent of blood pressureand cholesterol lowering effects. Kidney Int, 2000; 58(4): 1420-143

11. Ichiki T, Takeda K, Tokunou T, Lino N, Egashira K, Shimokawa H, Hiarno K, Kanaide H, Takeshita A. Downregulation of angiotensin II type 1 receptor by hydrophobic 3-hydroxy-3-methylglutaryl coenzyme A reductase inhibitors in vascular smooth muscle cells. Arterioscler Thromb Vasc Biol, 2001; 21(12):1896-190

12. Hernàndez-Perera $\mathrm{O}$, Pérez-Sala $\mathrm{D}$, Navarro-Antolín I, Sànchez-Pascuala R, Hernàndez G, Díaz C, Lamas S. Effects of the 3-hydroxy-3-methylglutaryl coenzyme A reductase inhibitors, atorvastatin and simvastatin, on the expression of endothelin-1 and endothelia nitric oxide synthase in vascular endothelial cells. J Clin Invest, 1998; 101(12):27112719

13. Mason JC, Ahmed Z, Mankoff R, Lidington EA, Ahmad S, Bhatia V, Kinderlerer A, Randi AM, Haskaoud D. Statin-induced expression of decayaccelerated factor protects vascular endothelium against complement-mediated injury. Circ Res, 2002; 91(8):696-703

14. Li JH, He NS. Prevention of iodinated contrastinduced nephropathy. Chin Med J, 2009; (Engl) 124(23):4079-4082

15. Tumlin J, Stacul F, Adam A, Becker CR, Davidson C, Lameire N, McCullough PA. Pathophysiology of contrast-induced nephropathy. Am J Cardiol,2006; 98(6A):14K-20K

16. Gleeson TG, Bulugahapitiya S. Contrast-induced nephropathy. Am J Roentgenol,2004; 183 (6): 16731689

17. Hung YM, Lin SL, Hung SY, Huang WC, Wang PY. Preventing radiocontrast-induced nephropathy in chronic kidney disease patients undergoing coronary angiography. World J Cardiol, 2012; 4(5):157-172

18. Al-Otaibi KE, Al Elaiwi AM, Tariq M, Al-Asmari AK. Simvastatin attenuates contrast-induced nephropathy through modulation of oxidative stress, proinflammatory myeloperoxidase and nitric oxide. Oxid Med Cell Longev,. doi:10.1155/2012/831748

19. Attalah N, Yassine L, Musial J, Yee J, Fisher K. The potential role of statins in contrast nephropathy. Clin Nephrol, 2004; 62(4): 273-278

20. Khanal S, Attallah N, Smith DE, Kline-Rogers E, Share D, O’Donnell MJ, Moscucci M. Statin therapy reduces contrast-induced nephropathy: an analysis of contemporary percutaneous interventions. Am J Med, 2005; $118(8): 843-849$ 
21. Patti G, Nusca A, Chello M, Pasceri V, D' Ambrosio A, Vetrovec GW, Di Sciascio G. Usefulness of statin pretreatment to prevent contrast-induced nephropathy to improve long-term outcome in patients undergoing percutaneous coronary intervention. Am J Cardiol,2008; 101(3):279-285

22. Jo SH, Koo BK, Park JS, Kang HJ, Cho YS, Kim YJ, Youn TJ, Chung WY, Chae IH, Choi DJ, Sohn DW, Oh BH, Park YB, Choi YS, Kim HS. Prevention of radiocontrast medium-induced nephropathy using short-term high-dose simvastatin in patients with renal insufficiency undergoing coronary angioplasty (PROMISS) trial- a randomized controlled study. Am Heart J,2008; 155(3): 499.e1-499.e8

23. Zhao JL, Yang YJ, Zhang YH, You SJ, Wu YJ, Gao RL. Effect of statins on contrast-induced nephropathy in patients with acute myocardial infarction treated with primary angioplasty. Int $\mathrm{J}$ cardiol,2008; 126(3):435-436

24. Bouzas-Mosquera A, Vázquez-Rodríguez JM, Calviño-Santos R, Vázquez-González N, CastroBeiras A Statin therapy and contrast-induced nephropathy after primary angioplasty. Int $\mathrm{J}$ Cardiol,2009; 134(3):430-431

25. Xinwei J, Xianghua F, Jing Z, Xinshun G, Ling X, Weize F, Guozhen H, Yunfa J, Weili W, Shiqiang L. Comparison of usefulness of simvastatin $20 \mathrm{mg}$ versus $80 \mathrm{mg}$ in preventing contrast-induced nephropathy in patients with acute coronary syndrome undergoing percutaneous coronary intervention. Am J Cardiol,2009; 104(4):519-524 (Abstract was used)

26. Yoshida S, Kamihata H, Nakamura S, Senoo T, Manabe K, Motohiro M, Sugiura T, Iwasaka T. Prevention of contrast-induced nephropathy by chronic pravastatin treatment in patients with cardiovascular disease and renal insufficiency. J Cardiol,2009; 54(2): 192-198

27. Toso A, Maioli M, Leoncini M, Gallopin M, Tedeschi D, Micheletti C, Manzone C, Amato M, Bellandi F. Usefulness of atorvastatin $80 \mathrm{mg}$ in prevention of contrast-induced nephropathy in patients with chronic renal disease.Am J Cardiol, 2010; 105(3):288-292

28. Kandula P, Shah R, Singh N, Markwell S, Bhensdadia N, Davaneethan SD. Statins for prevention of contrast-induced nephropathy in patients undergoing non-emergent percutaneous coronary intervention. Nephrology, 2010; (Carlton) 15(2):165-170

29. Ozhan H, Erden I, Ordu S, Aydin M, Caglar O, Basar C, Yalcin S, Alemdar R. Efficacy of short-term highdose atorvastatin for prevention of contrast-induced nephropathy in patients undergoing coronary angiography. Angiology, 2010; 61(7):711-714

30. Acikel S, Muderrisoglu H, Yildirir A, Aydinalp A, Sade E, Bayraktar N, Bal U, Ozin B. Prevention of contrast-induced impairment of renal function by short-term or long-term statin therapy in patients undergoing elective coronary angiography. Blood Coagul Fibrinolysis, 2010; 21(8):750-757

31. Patti G, Ricottini E, Nusca A, Colonna G, Pasceri V, D'Ambrosio A, Montinaro A, Sciascio GD. Shortterm, high-dose storvastatin pretreatment to prevent contrast-induced nephropathy in patients with acute coronary syndrome undergoing percutaneous coronary intervention (from the ARMYDA-CIN [Atortvastatin for reduction of myocardial damage during angioplasty-contrast-induced nephropathy] trial). Am J Cardiol,2011; 108(1):1-7

32. Muñoz MA, Maxwell PR, Green K, Hughes DW, Talbert RL. Pravastatin versus simvastatin for prevention of contrast-induced nephropathy. J Cardiovasc Pharmacol Ther,2011; 16(3-4):376-379

33. Li W, Fu X, Wang Y, Li X, Yang Z, Wang X, Geng W, Gu X, Hao G, Jiang Y, Fan W, Wu W, Li S. Beneficial effects of high-dose atorvastatin pretreatment on renal function in patients with acute STsegment elevation myocardial infarction undergoing emergency percutaneous coronary intervention. Cardiology, 2012; 22(3):195-202

34. Quintavalle C, Fiore D, De Micco F, Visconti G, Focaccio A, Golia B, Ricciardelli B, Donnarumma E, Bianco A, Zabatta MA, Troncone G, Colombo A, Briguori C, Condorelli G. Impact of high loading dose of atorvastatin on contrast-induced acute kidney injury. Circulation,2012; 126(25): 3008-3016

35. Pappy R, Stavrakis S, Hennebry TA, Abu-Fadel MS. Effect of statin therapy on contrast-induced nephropathy after coronary angiography: A metaanalysis. Int J Cardiol, 2011;151(3):348-353

36. Zhang T, Shen LH, Hu LH, He B. Statins for the prevention of contrast-induced nephropathy: a systematic review and meta-analysis. Am J Nephrol,2011; 33(4):344-351

37. Takagi H, Umemoto $\mathrm{T}$. A meta-analysis of randomized trials for effects of periprocedural atorvastatin on contrast-induced nephropathy. Int $\mathbf{J}$ Cardiol,2011; 153(3):323-337

38. Zhou Y, Yuan WJ, Zhu N, Wang L. Short-term, highdose statins in the prevention of contrast-induced nephropathy; a systematic review and meta-analysis. Clin Nephrol, 2011; 76(6):475-483

39. Zhang L, Zhang L, Lu Y, Wu B, Zhang S, Jiang H, Ge J, Chen H. Efficacy of statin pretreatment for the prevention of contrast-induced nephropathy: a metaanalysis of randomized controlled trials. Int $\mathrm{J}$ Clin Pract, 2011; 65(5):624-630

40. Zhang BC, Li WM, Xu YW. High-dose statin pretreatment for the prevention of contrast-induced nephropathy: a meta-analysis. Can J Cardiol, 2011; 27(6):851-858

41. Li Y, Liu Y, Fu L, Mei C, Dai B. Efficacy of shortterm high-dose statin in preventing contrast-induced nephropathy: a meta-analysis of seven randomized controlled trials. Plos One, 2012; 7(4):e34450 
42. Kwok CS, Pang CL, Yeong JK, Loke YK. Measures used to treat contrast-induced nephropathy: overview of reviews. Br J Radiol,2013; 86(1021): 20120272

43. Lopez-Novoa JM, Quiros Y, Vicente L, Morales AI, Lopez-Hernandez FJ . New insight into the mechanism of aminoglycoside nephrotoxicity: an integrative point of view. Kidney Int, 2011; 79(1): 3345

44. Ozbek E, Cekmen M, Ilbey YO, Simsek A, Polat EC, Somay A. Atorvastatin prevents gentamicin-induced renal damage in rats through the inhibition of $\mathrm{p} 38$ MAPK and NF- $\kappa B$ pathways. Ren Fail, 2009; 31(5):382-392

45. Antoine DJ, Srivastava A, Pirmohamed M, Park BK. Statins inhibit aminoglycoside accumulation and cytotoxicity to renal proximal tubule cells. Biochem Pharmacol, 2010; 79(4):647-654

46. Jabari M, Rostami Z, Jenabi A, Zahedi-Shoolami L, Mooraki A. Simvastatin ameliorates gentamicininduced renal injury in rats. Saudi J Kidney Dis Transpl, 2011; 22(6): 1181-1186

47. Iranian Registry of Clinical Trials. IRCT201301283449N11.

48. Elyasi S, Khalili H, Dashti-Khavidaki S, Mohammadpour A. Vancomycin-induced nephrotoxicity: mechanisms, incidence, risk factors and special populations. A literature review. Eur J Clincal Pharmacol, 2012; 68(9):1243-1255

49. Ladino M, Alex M, Schulman IH. Acute and reversible vancomycin nephrotoxicity: a case series. J Nephrol Res Transplant, 2008; 3:4-10

50. Nishino $\mathrm{Y}$, Takemura S, Minamiyama $\mathrm{Y}$, Hirohash $\mathrm{K}$, Ogino $\mathrm{T}$, Inoue $\mathrm{M}$, Okada $\mathrm{S}$, Kinoshita $\mathrm{H}$. Targeting superoxide dismutase to renal proximal tubule cells attenuates vancomycin-induced nephrotoxicity in rats. Free Rad Res, 2003; 37(4):372-379

51. Hazlewood KA, Brouse SD, Pitcher WD, Hall RG. Vancomycin-associated nephrotoxicity: grave concern or death by character assassination? Am J Med, 2011; 123(2): 182e1-7

52. King DW, Smith MA. Proliferative responses observed following vancomycin treatment in renal proximal tubule epithelial cells. Toxicol In Vitro, 2004; 18(6):797-803

53. Panonnummal R, Varkey J, Dinoop DR. Protective effects of atorvastatin against vancomycin induced nephrotoxicity in albino rats. Pharmacie Globale [IJCP], 2011; 2(8):1-6

54. Miller RP, Tadagavadi RK, Ramesh G, Reeves WB. Mechanisms of cisplatin nephrotoxicity. Toxins (Basel), 2011; 2(11): 2490-2518

55. Chirino YI, Pedraza-Chaverri J. Role of oxidative and nitrosative stress in cisplatin-induced nephrotoxicity. Exp Toxicol Pathol, 2009; 61(3):223-242

56. Ramesh G, Reeves WB. P38 MAP kinase inhibition ameliorates cisplatin nephrotoxicity in mice. Am J Physiol Renal Physiol, 2005; 289(1):F166-174
57. Chan KK, Oza AM, Siu LL. The statins as anticancer agents. Clin Cancer Res, 2003; 9(1):10-19

58. Li S, Wu P, Yarlagadda P, Vadjunec NM, Proia AD, Harris RA, Portilla D . PPAR $\alpha$ ligand protects during cisplatin-induced acute renal failure by preventing inhibition of renal FAO and PDC activity. Am J Physiol Renal Physiol, 2004; 286(3):F572-F580

59. İșeri $\mathrm{S}$, Ercan $\mathrm{F}$, gedik N, Yüksel $\mathrm{M}$, Alican İ. Simvastatin attenuates cisplatin-induced kidney and liver damage in rats. Toxicology, 2007; 230(23):256-264

60. Fujieda M, Morita T, Naruse K, Hayashi Y, Ishihara M, Yokoyama T, Toma T, Ohta K, Wakuguchi H. Effects of pravastatin on cisplatin-induced nephrotoxicity in rats. Hum Exp Toxicol, 2010; 30(7): 603-615

61. Roudier E, Mistafa O, Stenius U. Statins induce mammalian target of rapamycin (mTOR)-mediated inhibition of Akt signaling and sensitize p53-deficient cells to cytostaic drugs. Mol Cancer Ther, 2006; 5(11):2706-2715

62. Finlay GA, Malhowski AJ, Liu Y, Fanburg BL, Kwiatkowski DJ, Toksoz D. Selective inhibition of growth of tuberous sclerosis complex 2 null cells by atorvastatin is associated with impaired Rheb and Rho GTPase function and reduced mTOR/S6kinase activity. Cancer Res, 2007; 67(20):9878-9886

63. Sharyo S, Yokota-Ikeda N, Mori M, Kumagai K, Uchida K, Ito K, Burne-Taney MJ, Rabb H, Ikeda M. Pravastatin improves renal ischemia-reperfusion injury by inhibiting the mevalonate pathay. Kidney Int, 2008; 74(5): 577-584

64. An Y, Xin H, Yan W, Zhou X. Amelioration of cisplatin-induced nephrotoxicity by pravastatin in mice. Exp Toxicol Pathol, 2011; 63(3): 215-219

65. Khoshnoud MJ, Abdeh Moghbel BN, Geramizadeh B, Niknahad H. Effect of simvastatin on cisplatininduced nephrotoxicity in male rats. Iranian Journal of Pharmaceutical Sciences, 2011; 7(3): 165-173

66. Cheng CF, Juan SH, Chen JJ,Chao YC, Chen HH, Lian WS, Lu CY, Chang CI, Chiu TH, Lin H. Pravastatin attenuates carboplatin-induced cardiotoxicity via inhibition of oxidative stress associated apoptosis. Apoptosis, 2008; 13(7):883894

67. Naesens M, Kuypers DRS, Sarwal M. calcineurin inhibitor nephrotoxicity. Clin J Am Soc Nephrol, 2009; 4(12):481-508

68. Li C, Yang CW, Park JH, Lim SW, Sun BK, Yung JY, Kim SB, Kim YS, Kim J, Bang BK. Pravastatin treatment attenuates interstitial inflammation and fibrosis in a rat model of chronic cyclosporineinduced nephropathy. Am J Physiol Renal Physiol, 2004; 286(1):F46-F57

69. Nam HK, Lee SJ, Kim MH, Rho JH, Son YK, Lee SM, Kim SE, Kim KH, An WS. Rosuvastatin attenuates inflammation, apoptosis, and fibrosis in a 
rat model of cyclosporine-induced nephropathy. Am J Nephrol, 2013; 37(1): 7-15

70. Shahbazi F, Dashti-Khavidaki S, Khalili H, LessanPezeshki M. Potential renoprotective effects of silymarin against nephrotoxic drugs: a review of literature. J Pharm Pharm Sci, 2012; 15(1):112-123

71. Nassiri-Toosi Z, Dashti-Khavidaki S, Khalili H, Lessan-Pezeshki M. A review of the potential protective effects of pentoxifylline against druginduced nephrotoxicity. Eur J Clin Pharmacol, 2012; 69(5):1057-1073

72. Jafari A, Dashti-Khavidaki S, Khalili H, LessanPezeshki M. Potential nephroprotective effects of Lcarnitine against drug induced nephropathy: A review of Literature. Exp Opin Drug Saf, 2013 . Epub ahead of print.

73. Hosseinjani H, Moghaddas A, Khalili H. Nacetylcysteine for the prevention of non-contrast media agent-induced kidney injury. From preclinical to clinical evidence. Eur J Clin Pharmacol, 2013; 69(7):1375-1390

74. Kalam K, Marwick TH. Role of cardioprotective therapy for prevention of cardiotoxicity with chemotherapy: a systematic review and metaanalysis. Eur J Cancer, 2013. Epub ahead of print. Doi;1D.1016/j.ejca.2013.04.030

75. Singh PP, Singh S. Statins are associated with reduced risk of gastric cancer; a systematic review and metaanalysis. Ann Oncol, 2013. Epub ahead of print.

76. Bjarnadottir O, Romero Q, Bendahl PO, Jirström K, Rydén L, Loman N, et al. Targeting HMG-CoA reductase with statins in a window-of-opportunity breast cancer trial. Breast Cancer Res Treat, 2013; 138(2):499-508

77. Riella LV, Gabardi S, Chandraker A. Dyslipidemia and its therapeutic challenge in renal transplantation. Am J Transplant, 2012; 12(8): 1975-1982

78. Maharjan N, Bedi U, Arora R, Bhandari S, Dahal P, Khosla S. Impact of statins on cardiovascular outcomes in renal transplant recipients: a systematic review. Am J Ther, 2011; 18(3):e48-e54

79. Mehra MR, Raval NY. Metaanalysis of statins and survival in de novo cardiac transplantation. Transplant Proc, 2004; 36(5):1539-1541

80. Stein W, Schrepfer S, Itoh S, Kimura N, Vellotta J, Palmer O, Bartos J, Wang X, Robbins RC, Fischbein MP. Prevention of transplant coronary artery disease by prenylation inhibitors. J Heart Lung Transplant, 2011; 30(7):761-769

81. Solid organ transplantation. In: Dipiro JI, Talbert RL, Yee GC, Matzke GR, Wells BG, Posey LM (editors). Pharmacotherapy: a pathophysiologic approach. $8^{\text {th }}$ edition. McGraw-Hill, 2011.

Table 2. Metaanalysis of protective effects of statins against contrast-induced nephropathy

\begin{tabular}{|c|c|c|c|c|c|}
\hline $\begin{array}{l}\text { Number } \\
\text { of study } \\
\text { included }\end{array}$ & $\begin{array}{l}\text { Number } \\
\text { of } \\
\text { patients }\end{array}$ & Goal of study & Results & $\begin{array}{c}\text { Authors' } \\
\text { mentioned } \\
\text { limitations }\end{array}$ & Ref \\
\hline $\begin{array}{l}10 \text { studies (3 } \\
\text { randomized } \\
\text { and } 7 \\
\text { non- } \\
\text { randomized) }\end{array}$ & 32,729 & $\begin{array}{l}\text { To evaluate the } \\
\text { impact of statin } \\
\text { therapy on the } \\
\text { incidence of } \\
\text { CIN in patients } \\
\text { undergoing } \\
\text { coronary } \\
\text { angiography }\end{array}$ & $\begin{array}{l}\text { Overall, statin therapy might } \\
\text { be associated with a } \\
\text { significant reduction in the } \\
\text { incidence of CIN in patients } \\
\text { undergoing coronary } \\
\text { angiography. } \\
\text { According to the pooled } \\
\text { estimate across the } 3 \text { RCTs, } \\
\text { statin therapy reduced the } \\
\text { incidence of CIN non- } \\
\text { significantly. }\end{array}$ & $\begin{array}{l}\text { Inclusion of both } \\
\text { randomized and } \\
\text { non-randomized } \\
\text { studies, differences } \\
\text { in the definitions of } \\
\text { CIN among the } \\
\text { studies, variations in } \\
\text { the type, duration, } \\
\text { and dose of statins. }\end{array}$ & 35 \\
\hline $\begin{array}{l}6 \text { cohort } \\
\text { studies } \\
\text { and } 6 \text { RCTs }\end{array}$ & $\begin{array}{l}1,194 \\
\text { from } \\
\text { RCTs }\end{array}$ & $\begin{array}{l}\text { To evaluate the } \\
\text { effects of statin } \\
\text { pre-treatment on } \\
\text { CIN incidence }\end{array}$ & $\begin{array}{l}\text { Among } 6 \text { cohort studies } \\
\text { included in this meta- } \\
\text { analysis, } 4 \text { showed that } \\
\text { chronic statin therapy before } \\
\text { contrast administration had a } \\
\text { protective effect against } \\
\text { CIN. Based on RCTs, a non- } \\
\text { significant protective trend } \\
\text { toward decreased CIN } \\
\text { incidence was seen with } \\
\text { periprocedural short-term, } \\
\text { high-dose statin treatment. }\end{array}$ & $\begin{array}{l}\text { Combined } \\
\text { data of cohort } \\
\text { studies and } \\
\text { heterogeneous } \\
\text { RCTs, inclusion of } \\
\text { low-quality } \\
\text { studies for meta- } \\
\text { analysis }\end{array}$ & 36 \\
\hline 7 RCTs & 1251 & $\begin{array}{l}\text { To assess the } \\
\text { effects }\end{array}$ & $\begin{array}{lrr}\text { Results } & \text { showed a } \\
\text { statistically } & \text { significant }\end{array}$ & Not mentioned & 37 \\
\hline
\end{tabular}




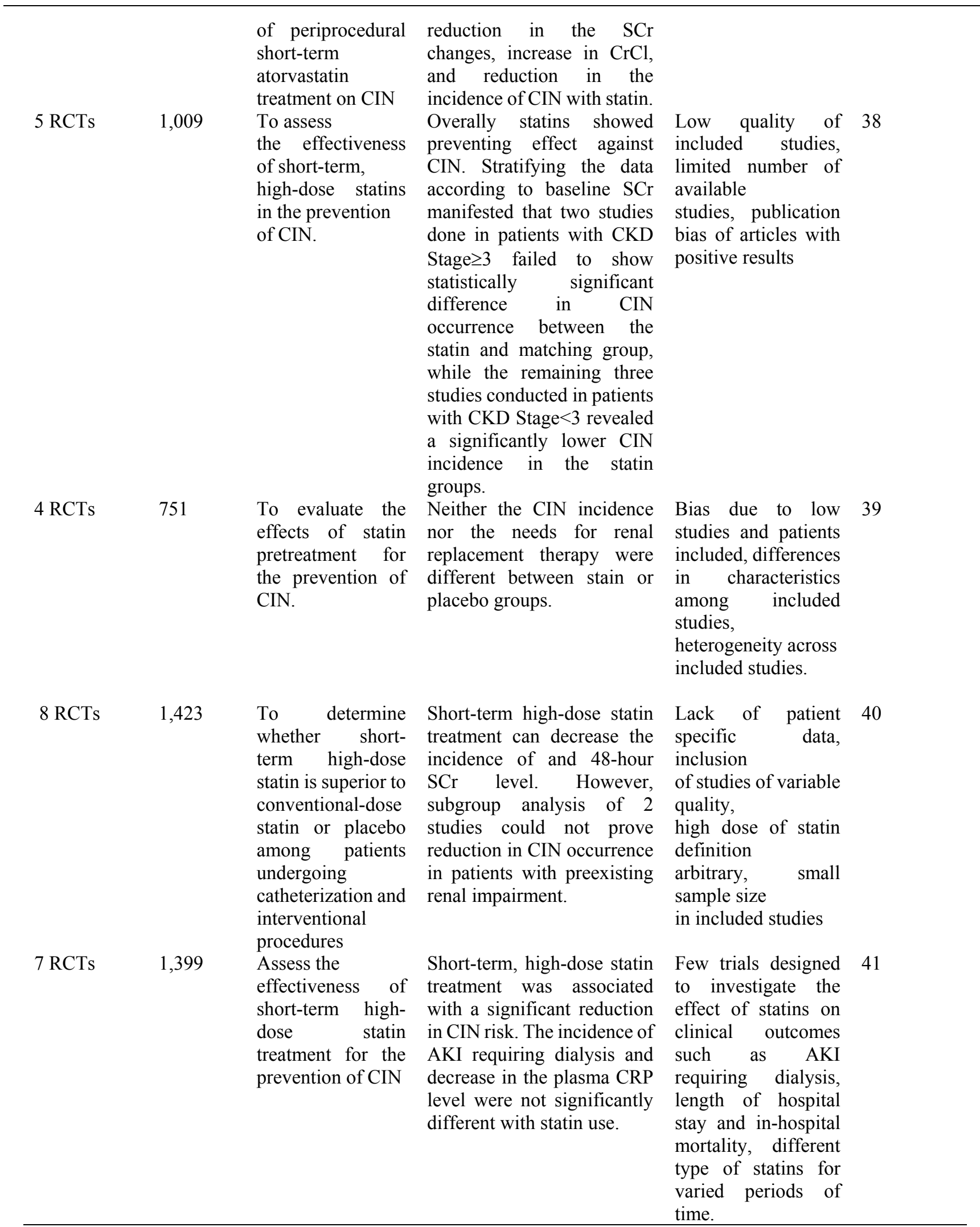

AKI: acute kidney injury; CIN: contrast-induced nephropathy; $\mathrm{CrCl}$ : creatinine clearance; CRP: C-reactive protein; RCT: randomized controlled trial; SCr: serum creatinine; 